\title{
Innovation in Sustainable Solar-Powered Net-Zero Energy Solar Decathlon Houses: A Review and Showcase
}

\author{
Yeganeh Baghi ${ }^{1, *}$, Zhenjun Ma ${ }^{1} \mathbb{D}$, Duane Robinson ${ }^{2} \mathbb{D}$ and Tillmann Boehme ${ }^{3}$ \\ 1 Sustainable Buildings Research Centre, University of Wollongong, Wollongong, NSW 2522, Australia; \\ zhenjun@uow.edu.au \\ 2 Australian Power Quality \& Reliability Centre, University of Wollongong, Wollongong, NSW 2522, Australia; \\ duane@uow.edu.au \\ 3 Sydney Business School, University of Wollongong, Wollongong, NSW 2522, Australia; tbohme@uow.edu.au \\ * Correspondence: yb790@uowmail.edu.au; Tel.: +61-2-4221-8111
}

check for updates

Citation: Baghi, Y.; Ma, Z.; Robinson,

D.; Boehme, T. Innovation in

Sustainable Solar-Powered Net-Zero Energy Solar Decathlon Houses: A

Review and Showcase. Buildings 2021,

11, 171. https://doi.org/10.3390/

buildings11040171

Academic Editor: David Arditi

Received: 7 March 2021

Accepted: 7 April 2021

Published: 16 April 2021

Publisher's Note: MDPI stays neutral with regard to jurisdictional claims in published maps and institutional affiliations.

Copyright: (C) 2021 by the authors Licensee MDPI, Basel, Switzerland. This article is an open access article distributed under the terms and conditions of the Creative Commons Attribution (CC BY) license (https:// creativecommons.org/licenses/by/ $4.0 /)$

\begin{abstract}
Solar Decathlon is a showcase of cutting-edge residential buildings containing innovative solutions and technologies. This study reviewed, identified, and categorized technological innovations from past Solar Decathlon competitions. The review was based on publicly available data of the top five houses from each U.S. and international Solar Decathlon competition. The most prolific innovations identified were from building services systems and architectural design and construction. It was observed that most innovations within building services systems were in heating, ventilation, and air-conditioning, and home automation, while architectural design and construction innovations focused on building adaptability, façade, structure, and building materials. It was found that although there is no fixed relationship between the numbers of innovations in the houses and their overall competition points, there is a high probability for an innovative house to be placed within the top five houses. This study also provides information about technological innovations within Solar Decathlon houses and offers an innovation classification scheme to guide Solar Decathletes to understand what innovations could be implemented in their future entries.
\end{abstract}

Keywords: technological innovation; sustainability; architectural innovation; construction innovation; building services innovation; building; net-zero energy; Solar Decathlon

\section{Introduction \\ 1.1. Innovation}

Sustainable development is part of the solution to high resource consumption in the building sector [1]. Hence, engineers in the building and construction industry need to think more innovatively to achieve sustainable development. Innovation enables companies to increase competitiveness [2,3], grow market share [4], and avoid lagging behind international perspectives or disappearing [3].

Eurostat and the Organization for Economic Co-operation and Development (OECD) jointly developed the "Oslo Manual" in order to study innovation [5]. Early editions of the manual focused on technological innovation in manufacturing from a product and process point of view, and later in 2005, organizational innovation was added. Based on this manual, the definition of innovation used through this research is "the implementation of a new or significantly improved product, or process, a new marketing method, or a new organizational method in business practices, workplace organization or external relations" [5]. The international Solar Decathlon (SD) competition houses were used as the data source in this study, since SD is a platform for implementation and showcase of technological innovations within the building and construction sector.

\subsection{Solar Decathlon}

$\mathrm{SD}$ is an international competition that challenges students to design, build and operate full-size solar-powered sustainable homes. Students involved in the project ranged 
from the undergraduate through to the Ph.D. levels from different disciplines. The SD competition, first held in 2002 by the U.S. Dept. of Energy, has intended to provide communities with information and education about opportunities and advantages of clean energy products for designing and building sustainable and high-energy efficient solar-powered houses and help encourage the implementation of net-zero energy homes. The competition is a showcase of affordability and comfort that combines energy-efficient construction and appliances with the renewable energy systems available today [6].

In SD, each house is judged based on 10 sub-contests (thus the term decathlon). Between 2002 and 2019, 16 competitions were held across nearly all continents. The location and innovation sub-contest detail for each competition are summarized in Table 1.

Table 1. Solar Decathlon competitions' sub-contests related to innovation. The asterisk indicates competitions that were considered for the analysis in this study.

\begin{tabular}{|c|c|}
\hline Solar Decathlon Competition & $\begin{array}{l}\text { Sub-Contests or Sub-Contest Component } \\
\text { (Innovation Related Points/Total Points) }\end{array}$ \\
\hline Europe 2019 & Innovation \& Viability Sub-contest $(100 / 1000)$ \\
\hline Middle East 2018 * & Innovation Sub-contest $(80 / 1000)$ \\
\hline China 2018 & Innovation Sub-contest $(100 / 1000)$ \\
\hline U.S. 2017 * & Innovation Sub-contest $(100 / 1000)$ \\
\hline Latin America 2015 & Viability \& Innovation Sub-contest $(100 / 1000)$ \\
\hline U.S. 2015 * & No specific innovation contest criteria \\
\hline China 2013 & No specific innovation contest criteria \\
\hline Europe 2014 * & Innovation Sub-contest $(80 / 1000)$ \\
\hline U.S. 2013 * & No specific innovation contest criteria \\
\hline Europe 2012 * & Innovation Sub-contest $(80 / 1000)$ \\
\hline U.S. $2011 *$ & No specific innovation contest criteria \\
\hline EUR 2010 * & Innovation Sub-contest $(80 / 1000)$ \\
\hline U.S. 2009 * & No specific innovation contest criteria \\
\hline U.S. 2007 * & No specific innovation contest criteria \\
\hline U.S. 2005 * & No specific innovation contest criteria \\
\hline U.S. 2002 * & $\begin{array}{l}\text { Presentation \& Simulation }(15 / 1100), \text { Comfort zone } \\
(30 / 1100), \text { Refrigeration }(30 / 1100) \text {, Hot water }(30 / 1100) \text {, } \\
\text { Lighting (20/1100) }\end{array}$ \\
\hline
\end{tabular}

\subsection{Importance of Innovation in the Solar Decathlon Competition}

SD is an innovation-based competition with multiple aims: (i) challenge students to develop innovative solutions; (ii) encourage professionals to reduce the environmental impact of their buildings by selecting the best materials and technologies; and (iii) educate the public about renewable energy, energy efficiency, responsible energy use, and available technologies in these areas [7]. SD is also a good way for government agencies to support/seed innovation [8]. In the SD competition, innovation is embedded in all project areas such as engineering, energy production, construction, and architecture [6-12]. Although innovation is important in SD contests, there is a lack of studies that highlight and summarize the innovations arising from SD competitions.

Innovation is increasingly becoming an important factor for the success of a project. While studies such as $[13,14]$ have reviewed specific innovative technologies in buildings, this paper is the first to document and analyse the concept of innovation in the SD competitions and offer a new classification method for technological innovations. It is expected that the findings obtained from this study can be used to facilitate the development and implementation of innovations in future Solar Decathlon competitions and innovations in the built environment.

\section{Method for Analysis and Classification of Innovation}

The proposed methodology for analysing the data on innovation from past SD contests is a qualitative research method using thematic analysis $[15,16]$. For this process, as there were approximately from 12 to 22 teams in each competition and there have been 16 
competitions since the inaugural event in 2002, the scope was limited to the top five ranked houses (by the competition points). The documents used for undertaking this research were: U.S. Dept. of Energy Solar Decathlon web-page [6], contest codes/rules [17-24], and reviews $[8,9,25]$ available from the various competitions as well as reports and house manuals from individual entrant web-pages, academic papers, and multimedia.

In order to analyse the data, general themes of the innovative technologies were first categorized and then applied to the individual SD house (Top 5). In the last step, the data was analysed by finding the number of innovations in each house and calculating the percentage of each innovation in the two main classifications of "building services" (BS) and "architecture and construction". The detail of the analysis is provided in Figure 1 and discussed in the following sections.

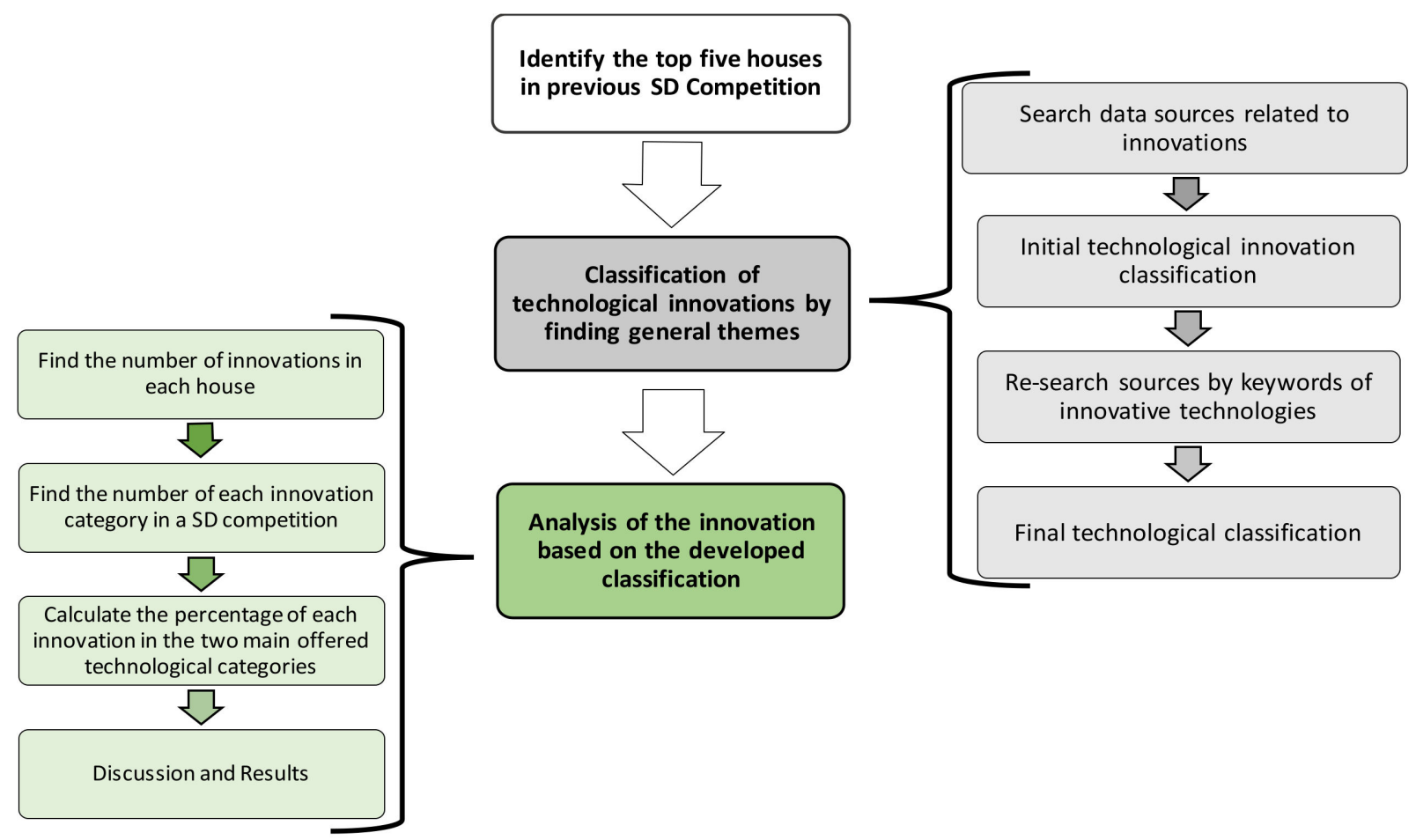

Figure 1. Data analysis methodology used in this study.

\section{Analysis of Solar Decathlon Competitions 2002-2019}

\subsection{Innovation Concept from the Perspective of Time in SD Contests}

From the perspective of time, the competition process can be divided into four temporal phases of pre-contest, competition development, contest period, and post-event (refer to Figure 2). The first phase can contain innovations in the conceptual design, name, and marketing of the house. Innovations in this phase determine the qualification to enter the competition. This is followed by the development and implementation phase, which stretches from early development to prototyping. In this phase, almost all elements such as communication, architecture, and building services are involved. This is followed by the period in which contestants build and operate the house at the competition location. The post-event phase mostly involves communications; however, there can be a major innovation in the destination of the house after the competition. Considering all these phases, the most significant opportunity for major technological innovations occurs in the development and implementation phase. 


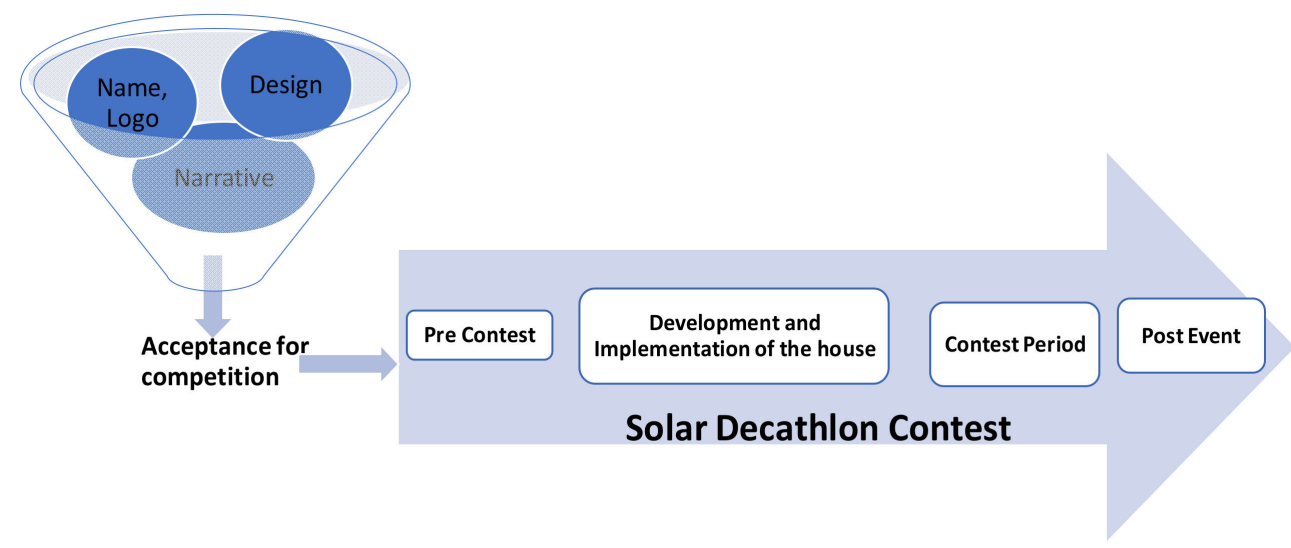

Figure 2. Innovation from the perspective of time during the SD Contest.

\subsection{Innovation Concept from the Perspective of Judgement in SD Contests}

In all SD competitions, the houses were judged based on 10 sub-contests. These sub-contests vary from one competition to another, and scores or judgment categories also change. Generally, the five sub-contests of architecture, engineering, energy balance (efficiency), thermal comfort, and house functioning have remained in all competitions.

There are various scoring methods for sub-contests: successful completion of tasks (e.g., washing dishes, cooking, and laundry to simulate real-life activities); measuring performance and monitoring (e.g., meeting certain $\mathrm{CO}_{2}$ levels, humidity, and temperature for thermal comfort); or expert jury perceptions. Jurors assess the house based on their expertise in the specific field in which specific measurements cannot, such as aesthetics, innovation, and design inspiration [9]. There were no fixed or certain identifiers for innovation judgement except for the expertise of the jury members.

Over the history of SD, innovation has been judged in two main ways: a scoring system (as part of a sub-contest or a separate sub-contest by itself); and special award. In the U.S. 2002 competition, "innovation and consumer appeal" was considered as part of the design presentation and simulation, comfort zone, refrigeration, hot water, communication, and lighting sub-contests. Innovation was not part of a U.S. SD competition sub-contest or a separate sub-contest until 2017. For the SD competitions held in other countries, innovation has remained a separate sub-contest, except for China 2013. Table 1 shows how the innovation judgment approach was changed over time from one SD to another. The innovation-related sub-contest has gained more attention and is considered a separate sub-contest in the last five SD competitions.

\section{Review of Innovations in Solar Decathlon Competitions}

The main innovations within the analysed SD contests, considering the top five houses, can be categorized as per Figure 3. This classification was developed through thematic analysis as explained in Section 2. As innovation into passive design features was previously analysed [26], the classification of technological innovation in the present study (from the subject of passive design) only considers building envelope, façade, and passive use of phase change materials (PCMs).

As shown in Figure 3, the two main categories of innovation are architectural design and construction and building services systems. In Sections 4.1 and 4.2, these classifications are evaluated by being applied to the cohort of the top five SD houses. 


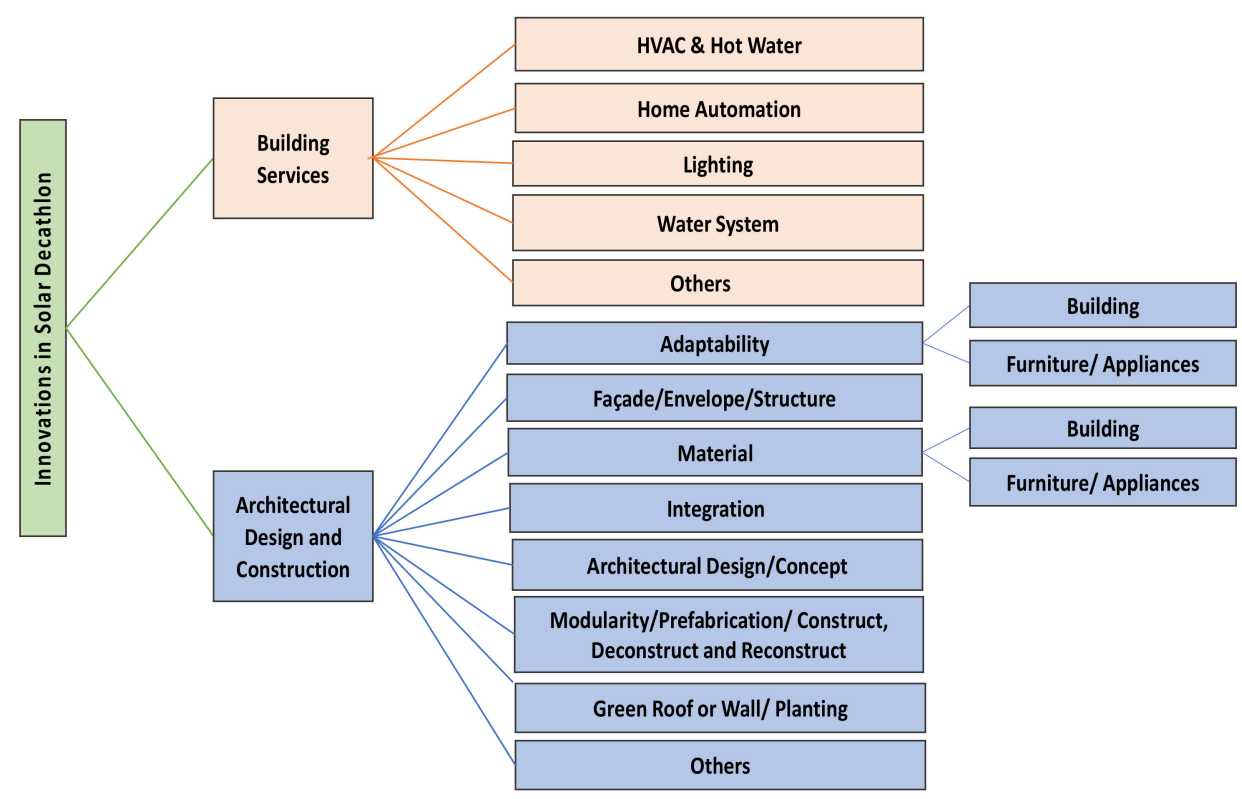

Figure 3. Classification of the technological innovations in SD competitions.

\subsection{Innovations in Building Services}

The abovementioned classification of innovations was applied to the cohort of the top five houses. Details of each classification are shown in Table 2. The percentage of each classified innovation within building services is shown in Figure 4.

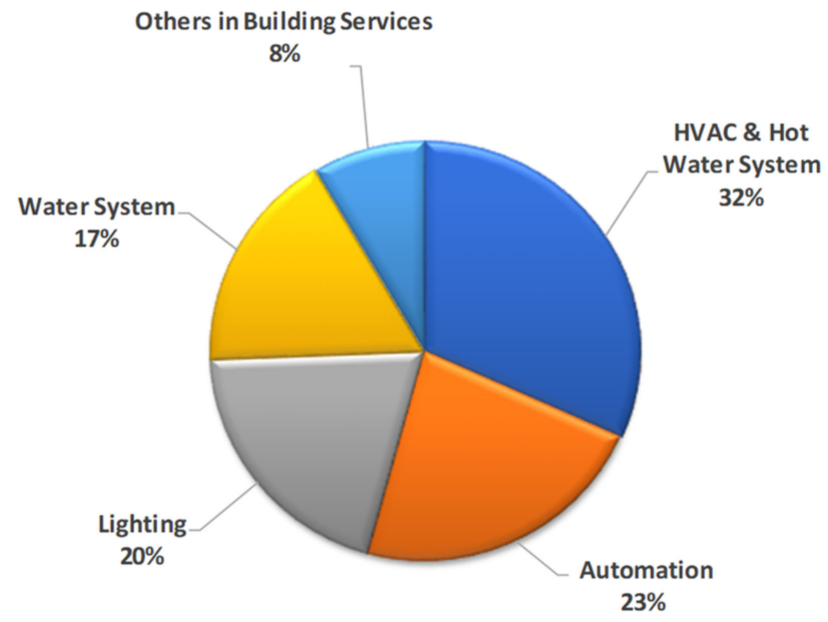

Figure 4. Building services innovations within the top five houses of SD competitions.

The highest percentage of innovations within building services has been in the area of heating, ventilation and air conditioning (HVAC) and hot water systems. This high percentage confirms opportunities for innovation in the HVAC area, and that innovative solutions are needed to maintain thermal comfort conditions while minimizing energy use. As an example, an energy-efficient HVAC system for the harsh desert climate of -Solar Decathlon Middle East (SDME) 2018 was difficult to design as HVAC systems are high energy users and mandatory for thermal comfort conditions. Increasing efficiency can raise the chance of success in innovation sub-contests. As such using a novel HVAC [27] system was key to the University of Wollongong Desert Rose Solar Decathlon house in winning the innovation sub-contest in SD Middle East 2018. The main innovations within the building services are presented in Table 2. 
Table 2. Main innovations in building services.

Innovation Category

HVAC \& Hot Water System $\begin{array}{ll}\text { - } & \text { Energy recovery ventilator (ERV) unit, desiccant energy recovery } \\ \text { ventilator (DERV) unit, heat recovery ventilator (HRV), [9,27-48] }\end{array}$

- Geothermal/ground source heat pump $[8,9]$

- Radiant (cooling/heating) floor/ceiling [9,10,27,29,35,37-39,49-53].

- $\quad$ Evacuated tube solar thermal collector $[32,33,38,41,54-56]$

- Control system senses conditions and takes inputs lighting, temperature moisture, and $\mathrm{CO}_{2}$ inside the house and adjusts mechanical systems accordingly by sending commands to receivers, motors, and valves,

Home Automation Controls shading, lighting, and HVAC

systems $[9,27,29,31,32,34,38,40,41,43-45,47-49,52,53,57,59,69-82]$.

- $\quad$ Predictive control strategies $[27,41,47]$.

- Ambient natural lighting: skylight/Solatube/optical fiber/sky-wall (made of translucent aerogel allowing daylight into the interior

Lighting spaces) [8,52,76,78,81,83-85]

- $\quad$ Light emitting diode (LED)/LED strip/LED framed in the plexiglass $[8,9,27,36,42,43,47-49,51,57,60,63,69,70,74,78,79,86-88]$.

- Hydroponic wetland/garden [10,35,44,87,91]

- $\quad$ Recovering and harvesting of the rainwater $[41,43,45,48,52,53,74,80]$.

- Aquaponics $[49,80]$

- Usage of natural domestic purifying plant/photo-ozonolysis/charcoal/bio-microbic recovering system [53,82,85]

- Hydronic dryer cupboard using the hot water generating from the sun for drying clothes [98].

- Zeolites in dishwasher [11,52].

- Hybrid application $[30,79,99]$.

- Home smart sensors including face recognition able to activate operations within the house based on the people detected [70].

- Interactive/Smart mirror $[47,48,59]$.

- $\quad$ Plug and play cable installation $[27,100]$.
- Desiccant system: desiccant wheel, waterfall, desiccant cooling $[27,30,35,36,57-59]$

- $\quad$ PCMs $[11,27,29,34,36,40,41,45,47,50,51,56,60-67]$

- Other HVAC Creative Solution $[8,39,58,59,68]$.

- Cooling/ventilation tower, evapotranspiration cooling $[49,51,69,70]$

- Designed/produced gateways as a mediator between two different protocols [27].

- Smartphone/touch-pad applications allow for instant modifications such as energy use, and power up the house, usage of touch-pads $[9,10,29,38,47,80]$.

- $\quad$ Dimming features $[44,52,57,82,89,90]$

- $\quad$ Lighting design, where switches with Radio Frequency (RF) emitters are used, along with RF adapters placed on the lights [78].

- Grey/black water collecting/treatment and re-use: irrigation, flushing etc. $[27,36,39,40,43,45,47,48,52,59,70,74,79,82,85,91-96]$.

- Joulia shower: shower pan with heat recovery $[37,41,52,97]$.

- $\quad$ Orbital system [47].

- Sun-tracking photovoltaics, which also serves as sunscreen on the rooftop terrace [41].

- Dye-sensitized solar panel [81].

- Innovative combination of the classical residual current device (RCD) and main circuit breaker (MCB) devices in the electrical system of the house, innovative RCD installation [79,100].

- Photoluminescent ceramic tiles [53].

- Luminous solar collector (LSC) [101] 
As an HVAC system is a set of different technologies and components, innovation could occur at different levels. For instance, for the dissipation of hot air, a heat recovery unit was located behind the refrigerator by the University of Colorado in the U.S. in 2002. This engineering design was marketable as it used off-the-shelf technologies [8]. Auburn University designed and decorated a room of their house with large water-filled cylinders and used them as thermal mass to moderate the building temperature by staying cooler in the summer and warmer in the winter [8]. The idea of grouping appliances together on a specific wall was implemented by Virginia Tech University to not only use them as serving tools but also consider them as a thermal buffer [8]. Radiant floor heating [9], ground source heat pumps [8,9], and evacuated tubes for hot water systems $[9,54]$ are among the technologies that have been used extensively and could be considered as the innovations at the time. An ERV [102] unit was used to minimize cooling and heating load. A custom manufactured DERV made of a non-toxic silica gel wheel, which exchanged heat and humidity between the intake and exhaust air was used by the Cornell University [28]. The liquid desiccant made up of calcium chloride mixed into the waterfall was an outstanding creative solution for controlling the humidity level in the house [57]. A prototype absorption chiller sized for residential use and designed to be tied up with the solar thermal system was a feature of the Santa Clara University HVAC system [103].

Phase Change Material has been applied in SD buildings in various ways to cool down or heat them up. Phase change gel was used under the floor as thermal mass by Universidad Politécnica de Madrid. The phase change gel helped heat the internal area by realizing the thermal energy on a winter night (Figure 5-left) and cool the house on a summer night (Figure 5-right) [55]. The same technology was applied by the Team Deutschland through microscopic-sized phase change material as Micronal plasterboards in their house. More innovation related to the HVAC innovations can be found in the study conducted by Ma et al. [104].
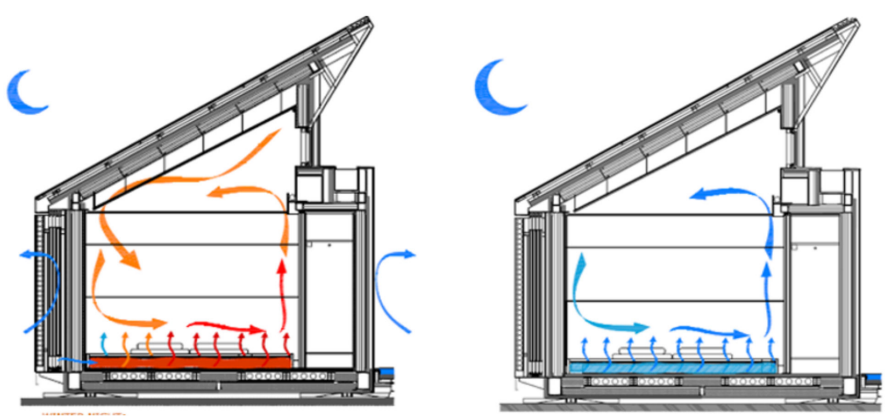

Figure 5. (Left): Winter night heating of phase change gel in the floor. (Right): Summer night cooling. Adapted from ref. [55].

Over the past SD competitions, innovations in automation systems have changed dramatically from simple controls to developed building management systems (BMS). In the U.S. in 2005, Cornell university used an automatic computerized control system for an ERV and its HVAC system [9]. Recently, the University of Wollongong's automation systems used KNX and digital addressable lighting interface (DALI) lighting protocols systems integrated with the Internet of Things (IoT), implemented in the Solar Decathlon house for the SDME 2018 [27].

Lighting the house is an important feature in any building. The usage of electrochromic windows allowed occupants to block or let the sun's rays pass through. Applying small voltage to the electrochromic glass results in darkening or lightening the house [105]. One of the specifications of Santa Clara University in the U.S. 2007 was applying Solatube, an innovation in daylighting system. As shown in Figure 6, it transferred the captured sunlight from the roof and distributed it throughout the room [83]. 


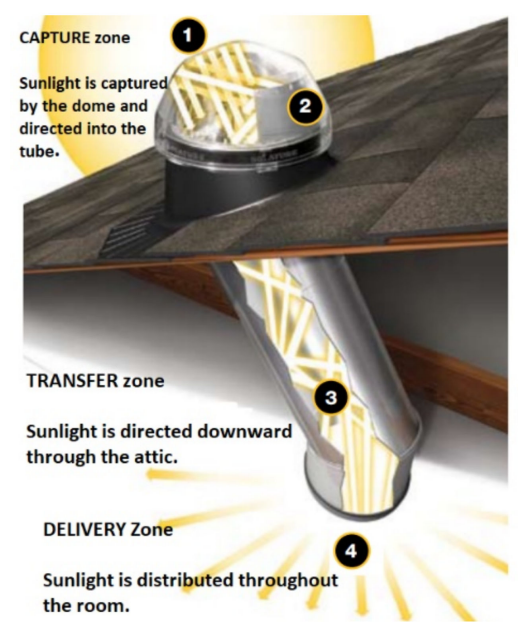

Figure 6. Solatube daylighting system. Adapted from ref. [83].

Auburn University skylight, which was filled with prisms to amplify sunlight for daylighting, was a different technique. Another interesting daylighting system was Skywall used by Virginia Tech. These outer walls were made up of a translucent aerogel material allowing daylight into the interior spaces [8,9]. The University of Virginia used a light-emitting diode wall as a climate control aspect [8]. This wall reflected the building's environmental condition through colour changes, showing whether the house is cool or warm.

Water is a precious and limited resource. Therefore, it is crucial to harvest, treat and reuse water. Many innovative solutions were implemented in the water waste systems and irrigation of the SD houses. As an example, water can be referred to as irrigation of the roof garden through the treated greywater from appliances [106]. More details about technological innovations in the SD houses are provided in Table 2. In conjunction with the innovations from building services, the second most significant collection of technological innovations came from architecture and construction, which will be discussed in the next section.

\subsection{Innovations in Architectural Design and Construction}

Applying the pre-offered classification shown in Figure 3 in the top five SD houses, the percentage of the categorized innovations in the architecture and construction was found and is presented in Figure 7.

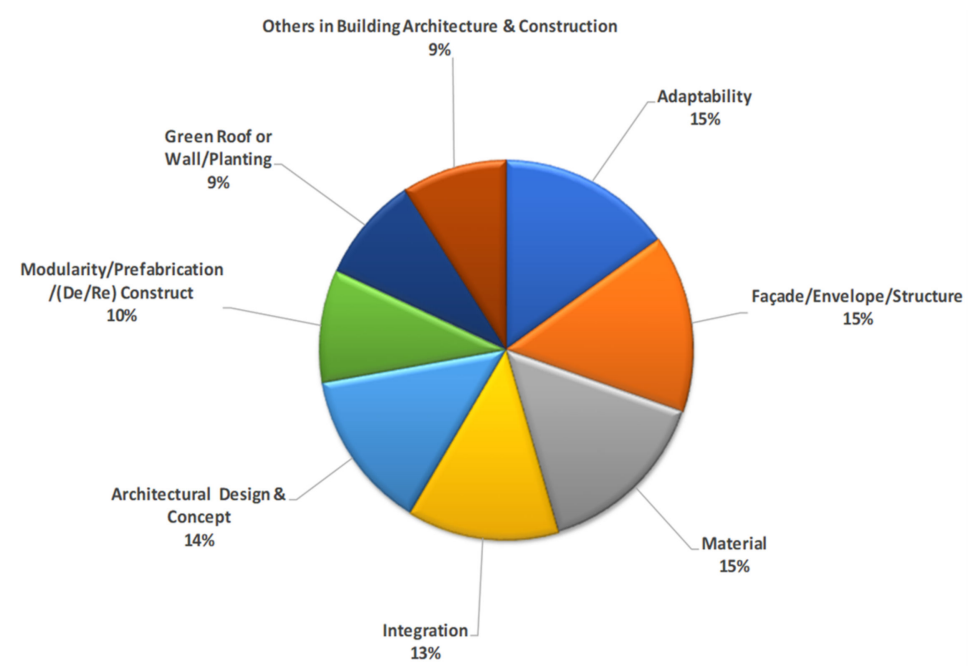

Figure 7. Architecture and construction innovations within the top five houses of SD competitions.

The main innovations for architectural design and construction are listed in Table 3. 
Table 3. Main innovations in architectural design and constructions.

\begin{tabular}{|c|c|c|}
\hline Innovation Category & \multicolumn{2}{|c|}{ Main Innovations in Architectural Design and Construction } \\
\hline Adaptability & $\begin{array}{ll}- & \text { Moveable roof/wall }[9,27,57,82,107] . \\
\text { - } & \text { NanaWall and shutters }[9,42,45,80,108] . \\
& \text { Sliding/folding door/Photovoltaic } \\
\text { - } & \text { panel/Screen }[27,37,43,45,52,55,80,87,109] . \\
\text { - } & \text { Folding faced awning system/curtain }[41,75] . \\
\end{array}$ & 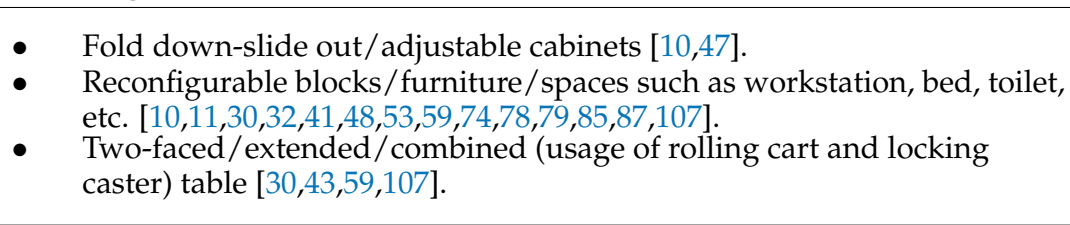 \\
\hline Façade/Envelope/Structure & 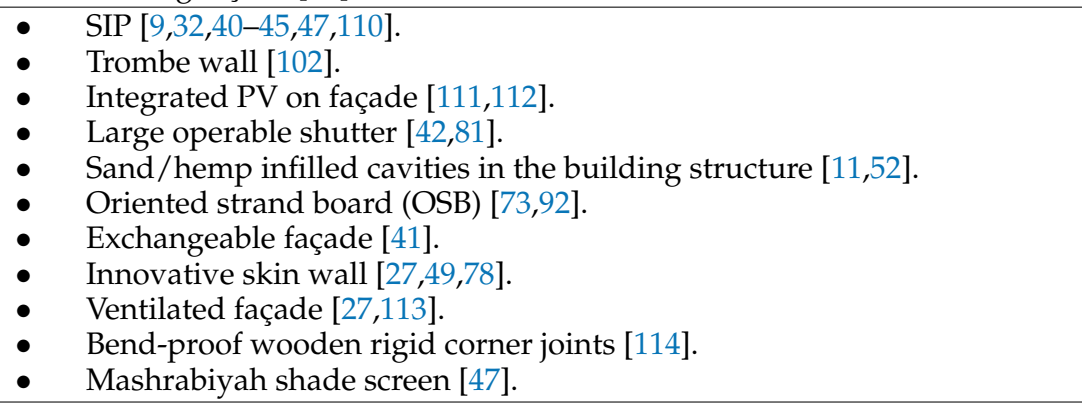 & $\begin{array}{ll}\text { - } & \text { Circular façade of laser-cut holes with folded tabs, laser cut-innovative } \\
& \text { screen [72,95]. } \\
\text { - } & \text { Façade layer of nanogel filled polycarbonate panels [72]. } \\
\text { - } & \text { Zigzag/jagged façade structure [96]. } \\
\text { - } & \text { Vacuum insulated panel [11]. } \\
\text { - } & \text { Façade made of disused CDs [36]. } \\
\text { - } & \text { Lucido façade system [52]. } \\
\text { - } & \text { Texture façade [37]. } \\
& \text { Structural bamboo (I-beams)/Lamboo frame [29,57,115]. }\end{array}$ \\
\hline Material & 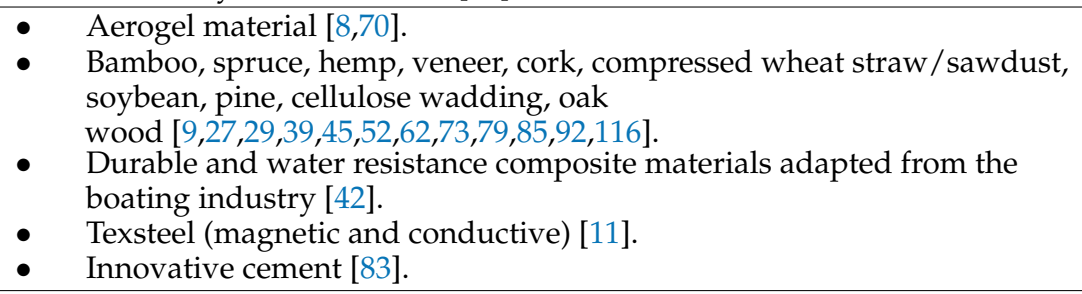 & $\begin{array}{ll} & \text { Milk bottles [57]. } \\
\text { - } & \text { Recycled steel, stone, glass, wood, aluminium }[27,49,53,57,69,79,117] . \\
\text { - } & \text { Harvested timber [36]. } \\
\text { - } & \text { Reclaimed wood, redwood plywood [36,40,49]. } \\
\text { - } & \text { Sustainable lystus floomp, recycled, foamed) concrete [27,41,57,99]. } \\
\text { - } & \text { 3D printing material [47]. }\end{array}$ \\
\hline Integration & $\begin{array}{l}\text { - } \quad \text { Integrated solar panel and awning }[8,9,47,48,106] \text {. } \\
\text { Building integrated photovoltaic (BIPV) in different elements, such as } \\
\text { shutters, façade, roof, } \\
\text { etc. }[27,29,37,41,42,48,49,56,57,79,81,99,100,119,120] \text {. }\end{array}$ & $\begin{array}{l}\text { - Integrated solar shingles [64]. } \\
\text { - } \quad \text { Bifacial PV in the façade [45]. } \\
\quad \text { Integration of the evacuated solar collectors in the envelope [121]. }\end{array}$ \\
\hline
\end{tabular}


Table 3. Cont

Innovation Category

Architectural Design

and Concept

Modularity/Prefabrication/D
Construction/Construction

Construction/Construction

Green roof or wall/planting

Others

Main Innovations in Architectural Design and Construction

- $\quad$ Core concept $[9,11,40,45,53,79,99]$

- $\quad$ Onion-like design [57].

- $\quad$ Skin system design blended in the green house [78].

- $\quad$ Single-room house [111]

- $\quad$ Butterfly roof $[122,123]$.

- Health-related designs $[27,118]$.

- 'Dry-flood-proofing' approach design [42].

- Design of self-supporting, custom-made ceiling elements used for distribution of conditioned air [81].

- House on a chassis so it could be moved to and from the location of competition in one piece/usage of the transportation system, built into house structure $[9,56]$

- $\quad$ Green roof, wall $[9,27,37,48,55,64,70,71,81,82,85,115,125,126]$. Vertical farm [11]

- $\quad$ Composting bin with included worms in the kitchen $[9,106]$

- Triple/quadruple-glazed, krypton/argon fill, low-e film windows $[27,29,49,62,85,89]$.

- $\quad$ Spider-shaped anchor for the anchoring system of the house [37].
- $\quad$ Conceptual landscape design [124].

- $\quad$ Saferoom design [59].

- Loggia with the modern application [53]

- A bent tubular design which controls the light entry [29].

- Home as a place of food production [43]

- A penthouse design as a solution to the city restoration and more living space in the old buildings [79]

- Greencourt [91].

- A container as part of the house [9].

- Prefabricated constructions, modular wall, roof $[9,27,45,49,52,53,70,79,81,116]$

- $\quad$ Greenhouse $[43,78]$

- Permaculture companion planting [91].

- Heat-trapping planters, canning table [43]

- $\quad$ Composting toilet [81,91].

- $\quad$ Solar dryer $[43,81,91]$

- Electro-chromic windows [105]. 
The integration of solar panels in a building was an innovation as it is adding extra value, such as shading and insulation to the building, while providing electricity. As an example, PV awning acted as a shading element (Figure 8) [9]. Also, providing overhangs through PV on the roof shaded the south-facing windows, which let the tenants enjoy better indoor comfort by having winter sun and omitting summer solar gain [106]. One of the most innovative integrations of PV in the building (BIPV) was implemented by team Technische Universität Darmstadt through applying PV into louvered oak shutters around the building, which provided adjustable shading (Figure 9) [71].

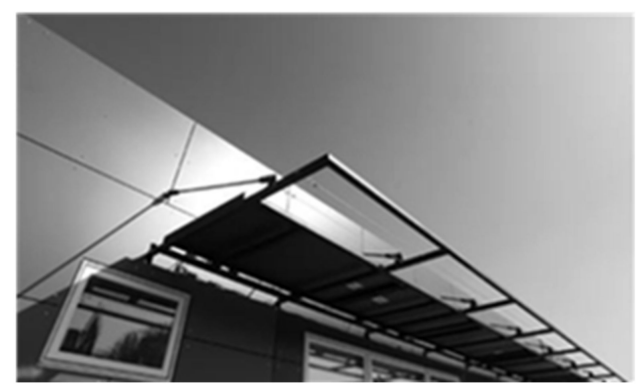

Figure 8. California Polytechnic PV awning. Reprinted from ref. [9].
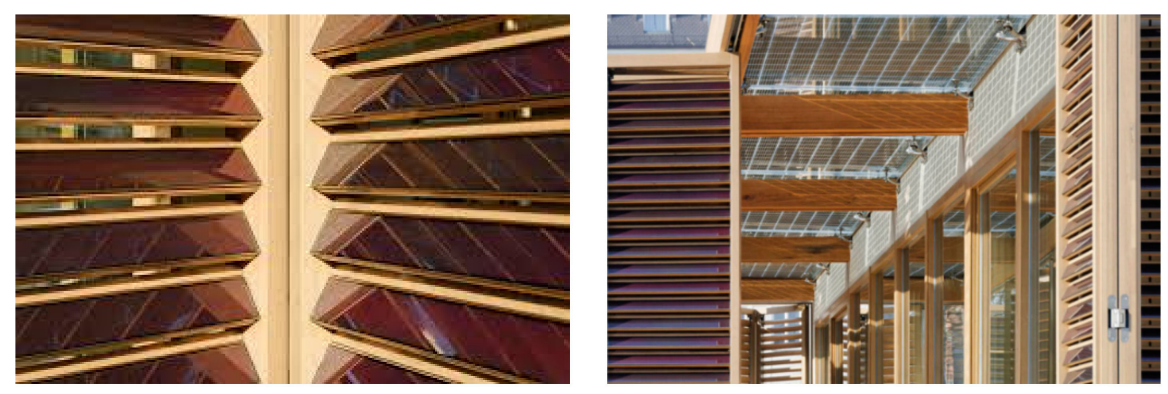

Figure 9. Technische Universität Darmstadt: (Left): BIPV in louvered oak shutters. Adapted from ref. [127]. (Right): BIPV awning. Adapted from ref. [128].

Moveable elements in the building could be considered innovative ideas. Moveable roof from [49] provided their house with the capability of adjusting openness and daylight entering the house. Moreover, NanaWall (i.e., a folding, rather than sliding glass wall between the living room and patio) provided a thermal seal as well as connected the interior and exterior spaces together [9]. Sliding doors and gliding room dividers [27] were other examples of moveable building elements that provide the building with more flexibility.

Usage of Structurally Insulated Panel (SIP) made up of various materials, as a primary building envelope/insulation, has been repeated [9]. The structure of SIP and materials used for its production can be considered innovative. Agriboard, a structurally insulated panel made of compressed wheat straw between two pieces of the oriented strand board [92], and BioSIP [129], were examples of SIP, as an innovative material for building construction used by the University of Colorado. More building construction system details can be found in the study conducted by Liu et al. [114].

Fast and economical ways to construct, deconstruct and reconstruct a building were another area for innovation. Prefabricated building structure [27] allows components to be built while minimizing the use of fossil fuels and construction logistics. As another solution, the New York Institute of Technology [9] used the transport shipping container to form the primary part of the house and contained the kitchen, bathroom, and mechanical systems. It included all the expensive components in a central core section. This prefabricated core was observed as adding market potential [9].

The selection of building materials played an important role in SD houses. The previously mentioned BioSIP, a patented wall type, was produced using lightweight but 
strong panels made from recycled materials which were filled with lightweight foam insulation (produced from soybean oil and waste paper) [9]. Usage of bio-fuel (bio-diesel) for transportation, as well as making furniture and tableware from natural materials such as soy, wheat, corn, and coffee [9] in civil and urban communities and cities can be considered as an innovation. Similarly, other material innovations included engineered wall panels, furniture, and cabinets using fast-growing woods from managed forests [129], and soybean-based insulation sprayed between wall studs, ceiling, and floor joists [92]. Innovative materials considering durability and sustainability included Lyptus [118] and bamboo flooring, and Trespa wall panels built by paper, wood fibre, and resin-based composite used for exterior and interior walls [116]. Homes have also featured a recycled milk bottle wall and structural bamboo I-beams [57]. Newly developed cement containing recycled material [83] is another example of innovation. More details on the skin material of the building have been offered by Zhang et al. [130] through case studies of Solar Decathlon Europe 2010.

Other innovations included: roof garden [9], green wall [49,70], usage of hydrogen fuel cell on the premises [9], composting bin with included worms in the kitchen [129], composting toilet [91], and Trombe wall [102].

The abovementioned innovations were identified and categorized. This classification could be used to develop the technological component of an innovation management framework.

\subsection{Innovations at Solar Decathlon Middle East 2018}

In November 2018, the Solar Decathlon competition was held for the first time in the Middle East. This competition was different from other Solar Decathlon competitions in terms of its location, where it was in a dry and humid climate of the desert. In the following section, some of the outstanding innovations of this competition are reviewed.

In SDME 2018, Virginia Tech University received first overall rank by presenting FutureHAUS, a prototype smart house built with smart construction techniques. The house was made of prefabricated modular structures that were pre-wired and pre-plumbed. These cartridges were designed in a way to be finished off-site and hooked up on-site using a plugand-play assembly method [47]. The suites of the cartridges are shown in Figure 10. This assembly method using prefabricated cartridges could provide a construction project with minimal site pollution, fast construction, and accurate scheduling, timeline, and pricing.
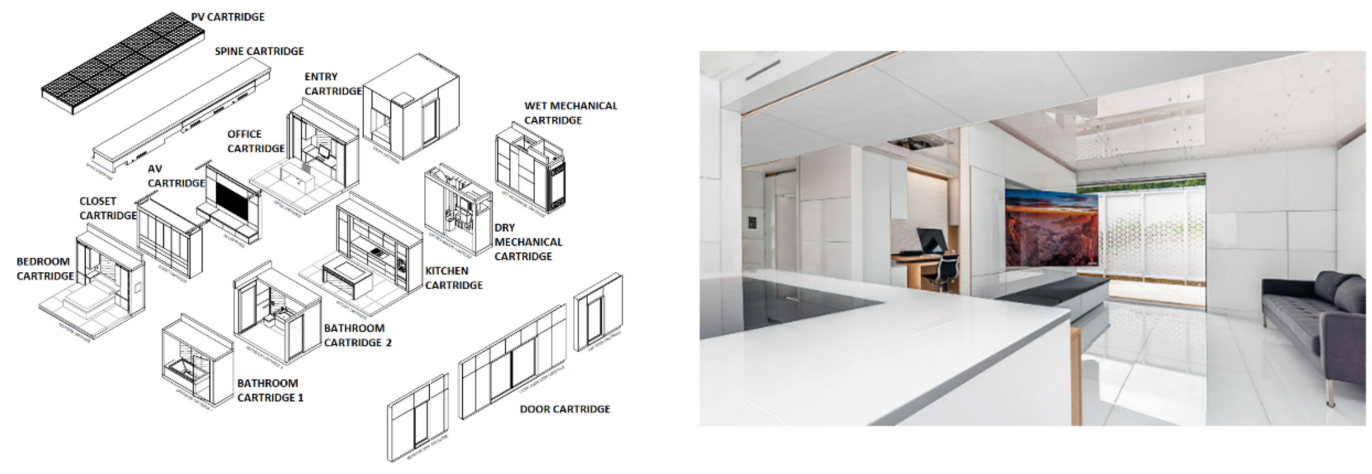

Figure 10. FutureHAUS. (Left): Suite of cartridges. Adapted from ref. [47]. (Right): Office and living room flex-space with rotating audio-visual (AV) wall, which could be moved mechanically. Reprinted from ref. [47].

The bathroom cartridge contained innovative features such as a smart mirror interface, a one-piece 3-D printed sink and countertop, and the toilet and vanity were height adjustable.

Team Virginia Tech implemented creative spatial flexibility in FutureHAUS called Flex-space. In this space, three program spaces of a home office, a bedroom, and a living room could be created through movable walls. The walls were powered by direct current (DC) through the conductive rail integrated to the house central spine cartridge which contained all home-run communication and electrical lines and all ductwork of the HVAC 
system. In the flex-space, the rotating AV wall shown in Figure 10 allowed the user to share the television and audio-visual technology between the living room and home office modes [47].

Team UOW from the University of Wollongong won second place in SDME 2018. Team UOW had a strong aim to change the way the world views homes for the elderly. Their innovative smart solar-powered Desert Rose was designed and developed to provide for occupants with age-related disabilities and diseases including dementia. The Desert Rose house innovative air to water HVAC system making use of on-site thermal storage and desiccant system provided the house with thermal comfort and suitable air conditioning based on the Dubai climate. The building integrated photovoltaic thermal (BIPVT) system of the house was innovative as they not only provided the house with electricity and hot water, they were also the roof structure of the house by themselves. The developed Model Predictive Control (MPC) was the major energy management strategy of the house. This MPC system along with the usage of KNX, DALI protocols, and IoT techniques led to the innovative smart automation system of the house. The digital water taps shown in Figure 11 include features like "tap on and off" functionality and free-spinning tapware. These novel taps could improve the quality of life for people with arthritis and dementia [131].

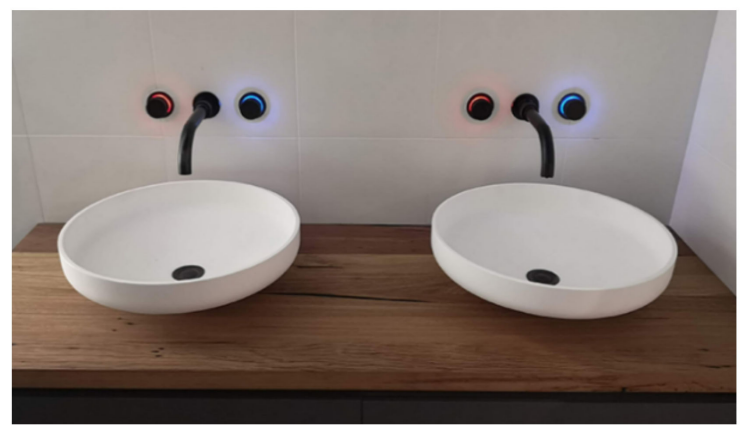

Figure 11. Innovative Desert Rose water tap. Reprinted from ref. [131].

In the Middle Eastern culture, having privacy is important. Considering this cultural aspect as well as reducing the heat gain from the harsh climate, an innovative façade was used. As an illustration, Team UOW Desert Rose house was wrapped by an innovative second skin wall made of a foamed concrete containing recycled crushed glass as a cement replacement. For the construction of this wall, instead of conventional steel reinforcement, carbon-fibre mesh reinforcement was used [27]. BAITYKOOL house, which won third place in the competition, had a similar envelope around it. This façade was made of ultra-high performance fibre-reinforced concrete [49]. The biomimetic solar cells [126] of this house were integrated in two different ways into the building. The first integration was within the façade and the second innovative way was BIPV in a movable roof over the patio. As shown in Figure 12, this movable roof could be closed and acts as a shading element throughout the day.
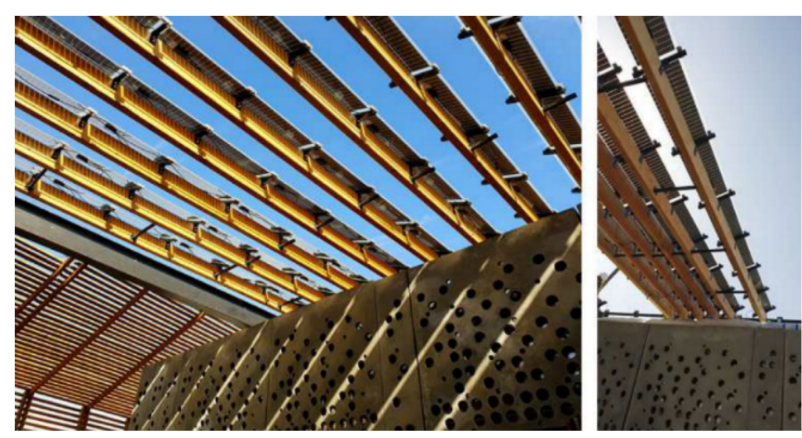

Figure 12. Movable PV integrated roof over BAITYKOOL house. Adapted from ref. [49]. 
A hybrid innovation was implemented in the water recycling system (Figure 13) of the BAITYKOOL house. The greywater could go through two ecological processes for filtration. The first stage was waste filtration through earthworms called lumbri-filtration, followed by treatment via Ultraviolet (UV) rays from the sun (bio-solar purification) [49]. The recycled water fed the ecosystems of the house, including the aquaponics system of the house for growing vegetables and raising edible fish.

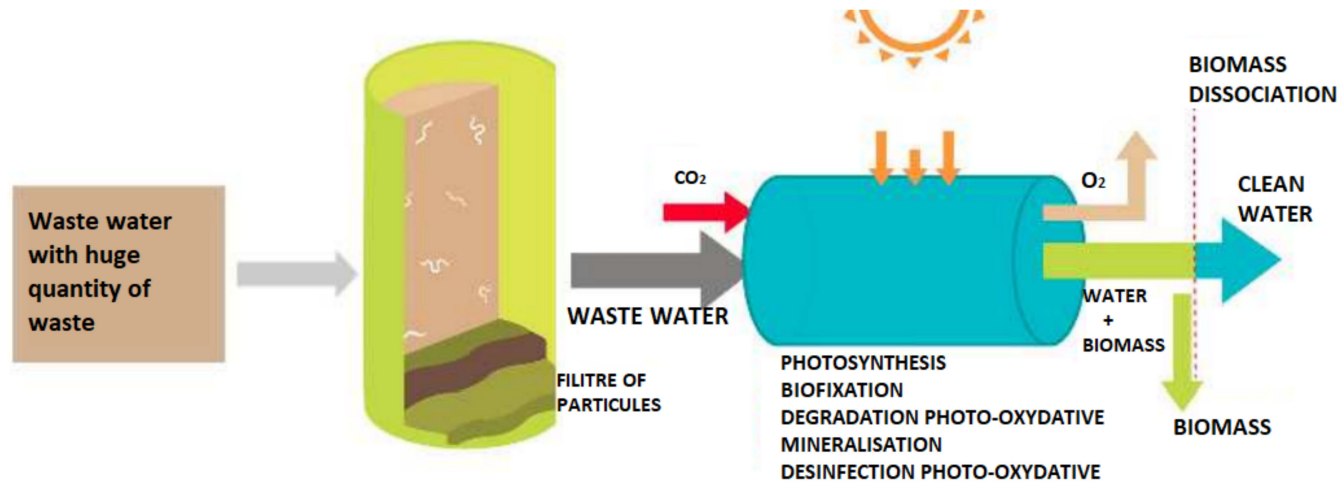

Figure 13. Greywater filtration of BAITYKOOL house. Adapted from ref. [49].

The Efden team won fourth overall rank in SDME 2018. They implemented hybrid innovative home automation based on energy efficiency and user experience. The automation system integrated the entire equipment into a programming logic controller (PLC), which runs the logic behind the automation scenarios. Integration of gateways for converting DALI to KNX and EnOcean to Modbus module made DALI and EnOcean compatible with the controller. A voice support system through which the occupants could use simple voice commands to find out the temperature and humidity of the house, access the lighting control system or operate the doors/windows open/closing mechanisms was created. This voice system was integrated into the automation via message queuing telemetry transport (MQTT)protocol; a Smart Mirror that displayed news, date and time, the weather forecast was developed. However, the most interesting feature about this mirror was the face recognition and understanding of the person's mood [48].

The University of Rome Sapienza implemented the concept of "innovative within tradition" by designing and building their smart solar house blended in with the Arab tradition and heritage. They combined a traditional internal patio with a green wall and a smart wall fountain integrated with the home automation system. Also, innovative augmentation of a wind tower (Figure 14) with an active air conditioning system was used. These combinations of modernity and tradition were implemented through an innovative building construction system with Cross Laminated Timber augmented with post-tensioning technique (Press-Lam), ventilated floor-wall connection technology, and innovative selective windows with advanced aluminium-wood frames enriched with aerogel thermal breaks [70]. The adaptive shading system with automated semitransparent light-reflective blinds and the car shading were other aesthetic innovative features of this house [70]. This electrical car canopy included a demonstrative off-grid PV system based on LSC [101] technology.

The above review showed that innovation has become an essential component in Solar Decathlon competitions to demonstrate how to use and implement innovative solutions and technologies to achieve net-zero energy consumption of solar-powered houses and how innovations assisted student teams in winning the competition. 


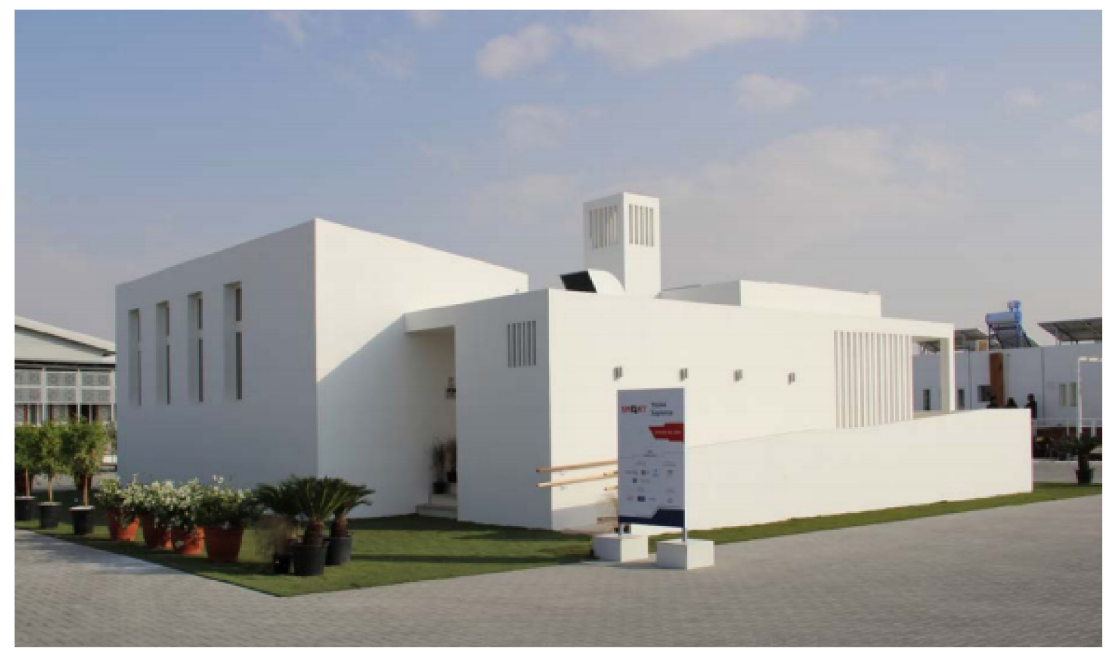

Figure 14. Sapienza house with semitransparent blinds and the wind tower. Reprinted from ref. [70].

\section{Discussion}

As part of the innovative solution, flexible designs such as a Murphy bed, moveable roof, and wall have been developed, which provide the building and furniture with more flexibility and adaptability. Another key innovation is to find efficient and fast ways to construct, deconstruct and reconstruct SD houses. For example, prefabricated constructed components, modular designs that fit into a shipping container, usage of the container as part of the building, and number-coded prefabricated construction systems, which allow non-builders to construct a house and/or reduce the construction logistics, are among the methods being considered.

There is no linear or fixed relationship between the technological innovation features of an SD house and its overall ranking in the contest. However, it can be concluded that innovation can assist the house to stay among the top five. As an example, the University of Maryland participated in four SD competitions (2002-4th, 2007-2nd, 2011-1st and 20172nd). The innovations of their entries were radical and incremental. The liquid desiccant waterfall (LDW) system was first used in LEAFHouse in 2007; and later in 2011, the improved LDW was employed in the WaterShed house. Although each time their entry had innovative features, the overall rankings did not follow any trend (other than being highly rated) (shown in Figure 15). One reason is that innovative features do not necessarily help houses to function to competition requirements. Another reason is that the innovation concept is quite broad; contests, sub-contests, and judgment, as well as grading approaches, change from one SD to another. In summary, there is a lack of fixed/equal identifiers for innovation judgment.

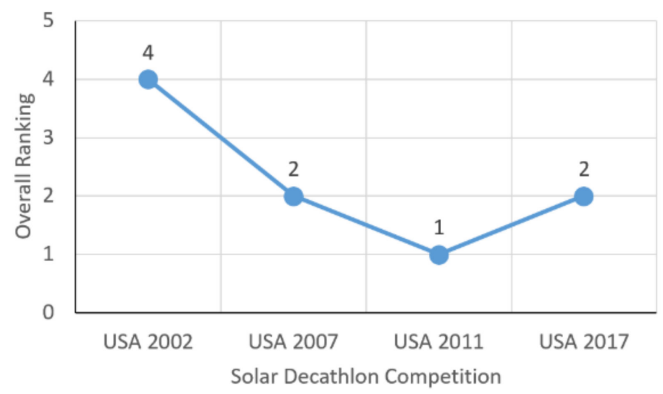

Figure 15. The overall ranking of the University of Maryland in four Solar Decathlons.

In SDME 2018, Desert Rose won first place in the innovation sub-contest and second overall. Figure 16 shows the details of the innovation sub-contest in that competition. Team Virginia Tech won the overall competition and Team UOW and Baitykool were respectively 
placed in the second and third overall. Figure 17 also confirms the abovementioned assertion in that there is no direct relationship between the ranking and number of innovations in the top five houses within any of the SD competitions.

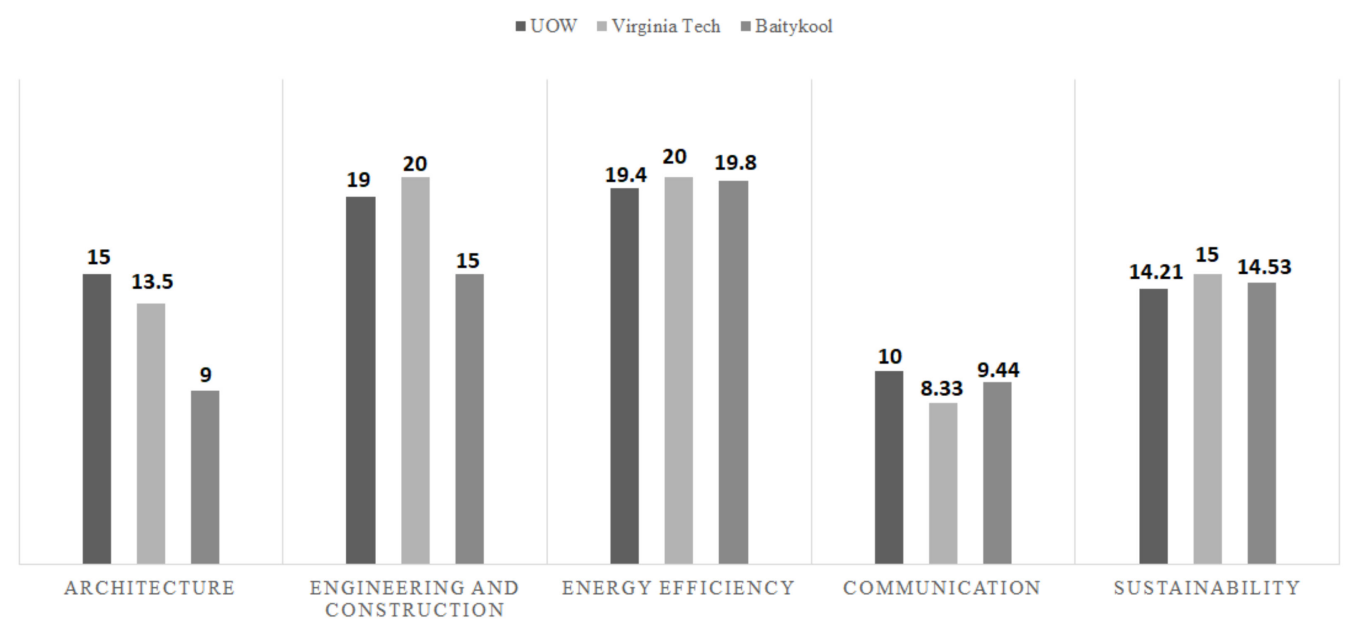

Figure 16. Innovation contest scoring for Team UOW and place getters in SD Middle East 2018.

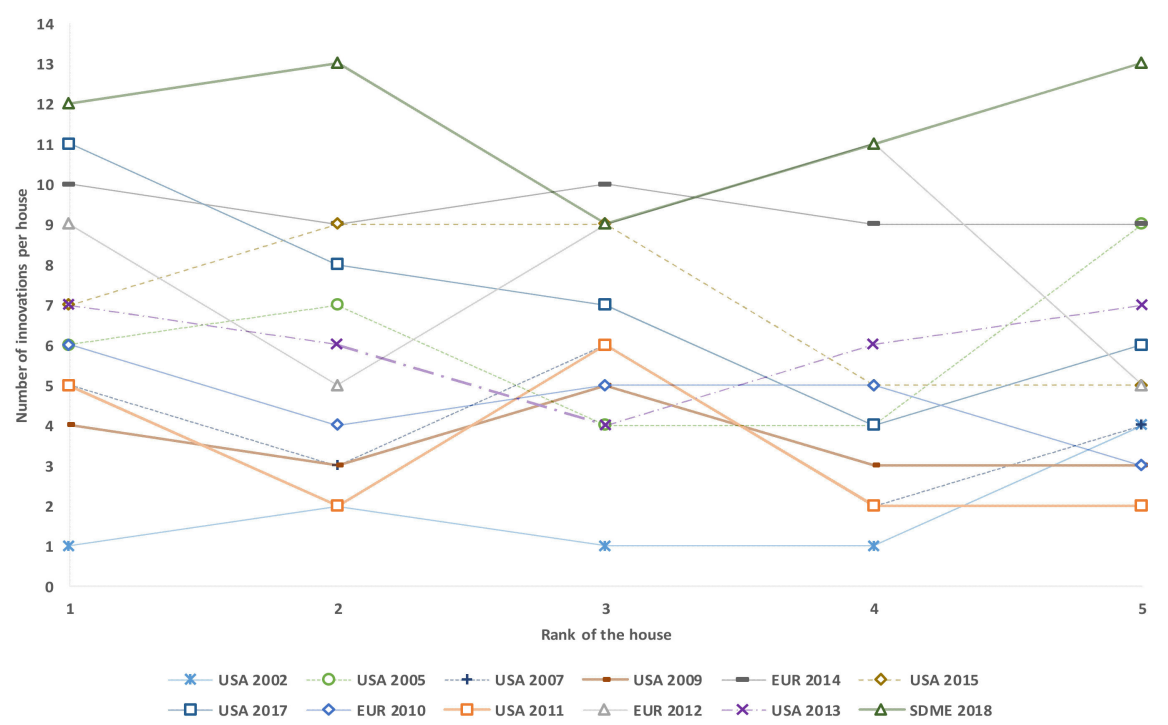

Figure 17. Innovations versus the ranking of the houses in the competition.

In general, it was found that the most innovations were implemented in HVAC, architectural design, adaptability of the building appliances to different lifestyles and climates, building materials, and integration of different features into the body of the building.

Figure 18 illustrates the number of total innovations in the first top-five houses in the SD competitions. Overall, before 2015, the competitions in Europe had more innovations than those held in the U.S. In recent years, the total innovations in the houses ranked 1st to 5 th were increased. This could be due to the advances in technology innovations providing teams with easier and economical ways to implement their ideas. As discussed in the previous sections, SD competitions commenced in 2002, and this long history provides teams with more data and information compared to the teams in the early stages of competitions. Therefore, being more familiar with the process and rules of competitions can have an impact on the selection of a successful innovative idea or process of implementation. As an illustration, new teams are able to add values to a previously defined and developed innovative idea from the past SD houses, such as usage of DALI protocol for LED strips which was an innovation from early competitions, or integrating Google Home to the BMS of the house. Figure 18 also shows that most innovations occurred in the 1st-placed houses. 


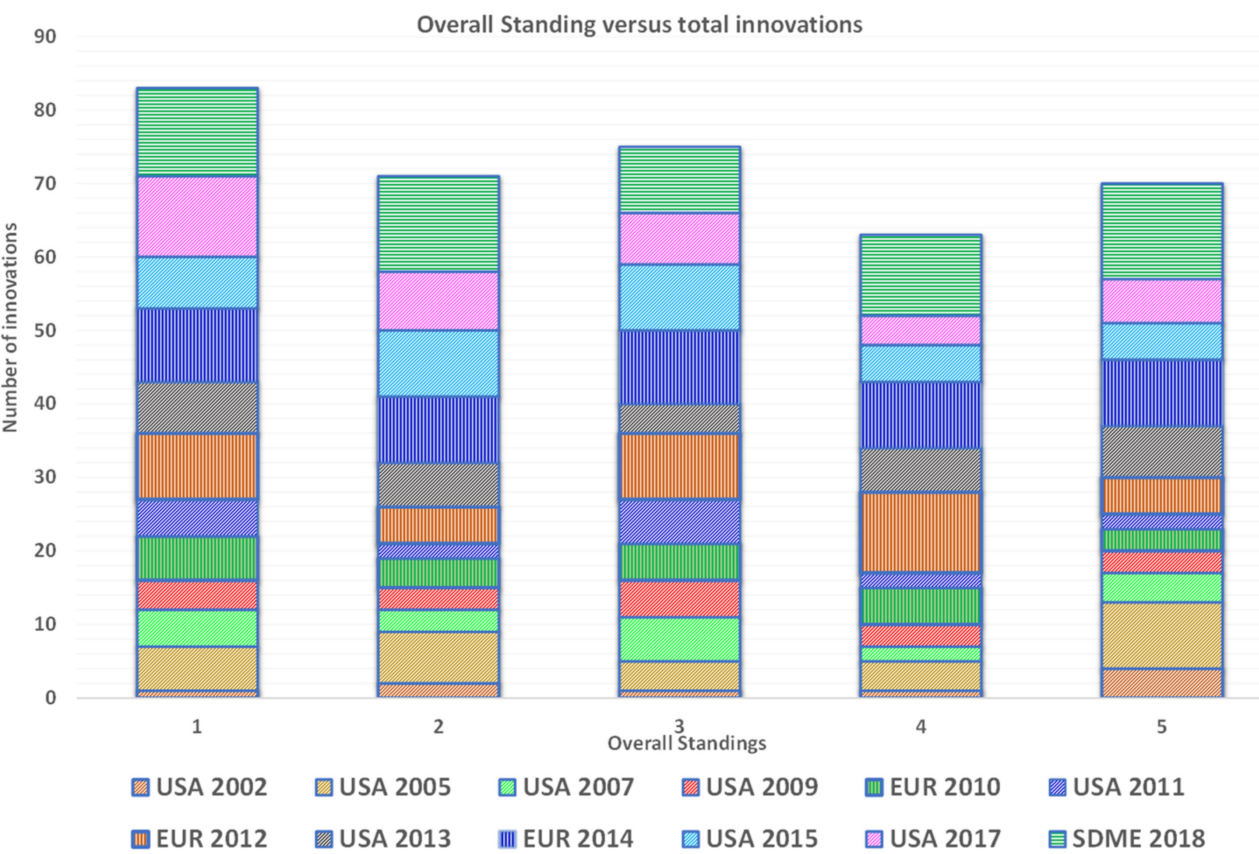

Figure 18. Overall standing versus total innovations in SD competitions.

As shown in Table 4 and mentioned above, more innovations were implemented in building services than those in architecture and construction. The innovation percentages increase as the competition time approaches the year 2017. This table has been compiled by considering only the top five houses in each of the SD competitions.

Table 4. Percentage of innovations in SD competitions between 2002 and 2018.

\begin{tabular}{|c|c|c|c|c|c|c|c|c|c|c|c|c|c|}
\hline 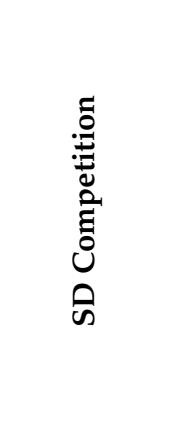 & 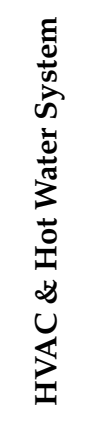 & 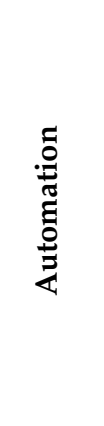 & & 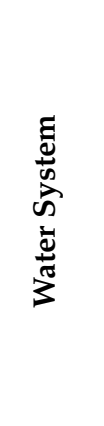 & 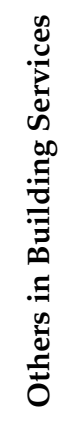 & 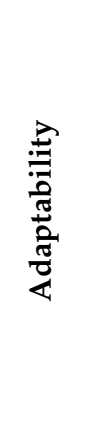 & 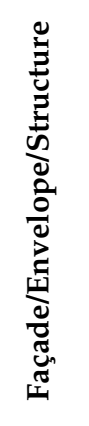 & 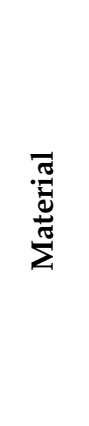 & 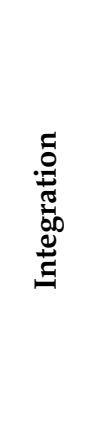 & 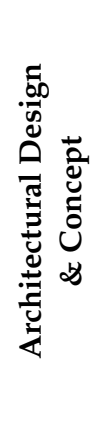 & 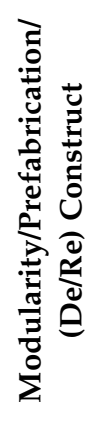 & 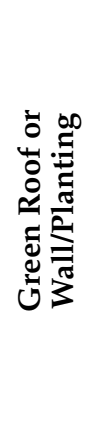 & 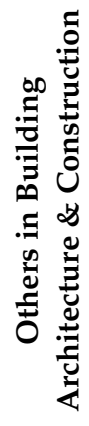 \\
\hline USA 2002 & $80 \%$ & $0 \%$ & $60 \%$ & $0 \%$ & $0 \%$ & $0 \%$ & $0 \%$ & $10 \%$ & $10 \%$ & $0 \%$ & $0 \%$ & $0 \%$ & $0 \%$ \\
\hline USA 2005 & $100 \%$ & $10 \%$ & $40 \%$ & $10 \%$ & $0 \%$ & $40 \%$ & $80 \%$ & $80 \%$ & $40 \%$ & $10 \%$ & $80 \%$ & $10 \%$ & $60 \%$ \\
\hline USA 2007 & $80 \%$ & $60 \%$ & $60 \%$ & $0 \%$ & $40 \%$ & $10 \%$ & $40 \%$ & $0 \%$ & $10 \%$ & $10 \%$ & $0 \%$ & $40 \%$ & $10 \%$ \\
\hline USA 2009 & $100 \%$ & $40 \%$ & $0 \%$ & $0 \%$ & $0 \%$ & $0 \%$ & $40 \%$ & $40 \%$ & $60 \%$ & $40 \%$ & $0 \%$ & $10 \%$ & $10 \%$ \\
\hline EUR 2010 & $80 \%$ & $10 \%$ & $40 \%$ & $10 \%$ & $10 \%$ & $40 \%$ & $60 \%$ & $40 \%$ & $40 \%$ & $40 \%$ & $40 \%$ & $0 \%$ & $10 \%$ \\
\hline USA 2011 & $100 \%$ & $80 \%$ & $0 \%$ & $0 \%$ & $10 \%$ & $40 \%$ & $10 \%$ & $0 \%$ & $10 \%$ & $40 \%$ & $0 \%$ & $10 \%$ & $0 \%$ \\
\hline EUR 2012 & $100 \%$ & $80 \%$ & $60 \%$ & $80 \%$ & $40 \%$ & $60 \%$ & $60 \%$ & $100 \%$ & $10 \%$ & $60 \%$ & $60 \%$ & $10 \%$ & $40 \%$ \\
\hline USA 2013 & $100 \%$ & $80 \%$ & $10 \%$ & $60 \%$ & $0 \%$ & $40 \%$ & $40 \%$ & $60 \%$ & $40 \%$ & $40 \%$ & $10 \%$ & $40 \%$ & $10 \%$ \\
\hline EUR 2018 & $100 \%$ & $100 \%$ & $100 \%$ & $80 \%$ & $80 \%$ & $100 \%$ & $80 \%$ & $60 \%$ & $80 \%$ & $80 \%$ & $40 \%$ & $40 \%$ & $10 \%$ \\
\hline USA 2015 & $100 \%$ & $80 \%$ & $100 \%$ & $80 \%$ & $0 \%$ & $80 \%$ & $60 \%$ & $40 \%$ & $40 \%$ & $60 \%$ & $10 \%$ & $10 \%$ & $10 \%$ \\
\hline USA 2017 & $10 \%$ & $80 \%$ & $80 \%$ & $100 \%$ & $40 \%$ & $80 \%$ & $10 \%$ & $10 \%$ & $40 \%$ & $80 \%$ & $40 \%$ & $60 \%$ & $60 \%$ \\
\hline SDME 2018 & $100 \%$ & $100 \%$ & $100 \%$ & $100 \%$ & $80 \%$ & $80 \%$ & $100 \%$ & $100 \%$ & $100 \%$ & $60 \%$ & $80 \%$ & $80 \%$ & $80 \%$ \\
\hline
\end{tabular}

Innovation is a broad topic and its concept can change over time, i.e., a product which is considered as a novel technology this year, may not be an innovation in the next 
year. In some cases, adding value to previous innovations can result in a new product or service which will be an incremental innovation. Successful innovations may continue to be included in newly built houses.

It is worthy to mention that innovative technologies in a house are not limited to the building itself. As an example, building an electrical vehicle (EV) [132] charger can provide energy for electric transportation systems. SDME 2018 competition provided the competition teams with testing ground for new ideas in housing as well as urban planning and sustainable transportation. Therefore, the solar-powered houses are required to produce enough energy to cover the demand of the building and the eco-friendly vehicle. The energy consumption for EV chargers should be monitored and controlled through the BMS of the house. For instance, the Desert Rose house BMS is able to control and monitor HVAC systems, EV charger, windows, lighting, smart appliances and the renewable energy systems [27].

$\mathrm{SD}$ is a suitable vehicle for showcasing and making innovative prototypes as the scientific and business sectors can come together and make changes by offering prototypes that will be operated and tested during competition and prepared for market.

\section{Conclusions}

In this study, technological innovations in the top five ranked sustainable net-zero houses in the Solar Decathlon competitions have been analysed. This was completed by applying thematic qualitative analysis. Consequently, the final classification has been derived. The classifications identified the areas where technological innovations have happened the most. It was found that the innovations in HVAC and home automation were the most focused technological innovations within building services, while within architectural design and construction, most innovations were in the adaptability of the building to lifestyles and climates, façade and structure, and building materials.

Based on this study, there is no direct relationship between the technological innovation features of SD houses and their overall ranking in the competition. However, it can be concluded that innovation helped the student teams to be placed among the top five houses in the competition. For example, the Desert Rose house in the Solar Decathlon Middle East 2018 won first place in the innovation sub-contest; however, it received the second overall ranking. Also, it was observed in recent years, specifically after 2017, that the innovation percentages have increased. This can be because of the advances in technology which provide SD teams with economical and improved ways to implement their innovative idea. The greater usage of incremental innovations can be another reason for this increase.

In this review, a technological innovations classification was developed that is a suitable tool for researchers, building and construction sector practitioners, and future Solar Decathletes. The developed classification is a fundamental starting point for establishing standards for an innovative net-zero sustainable house. It can also be used for future solar decathlon judgment criteria (with respect to both identifiers and weightings). Furthermore, the classification is a key component for developing the technological component of a sustainability-oriented innovation management framework for buildings. Moreover, the offered innovation quantification shows where in the building and construction sector, innovative sustainable technologies are more needed and can be applied in order to address sustainable developments needs of this sector.

Author Contributions: Conceptualization, Z.M.; methodology, Y.B. and Z.M.; validation, Z.M., D.R. and T.B.; formal analysis, Y.B.; investigation, Y.B.; data curation, Y.B.; writing-original draft preparation, Y.B.; writing-review and editing, Y.B., Z.M., D.R. and T.B.; visualization, Y.B.; supervision, Z.M., D.R. and T.B. All authors have read and agreed to the published version of the manuscript.

Funding: This research received no external funding.

Conflicts of Interest: The authors declare no conflict of interest. 


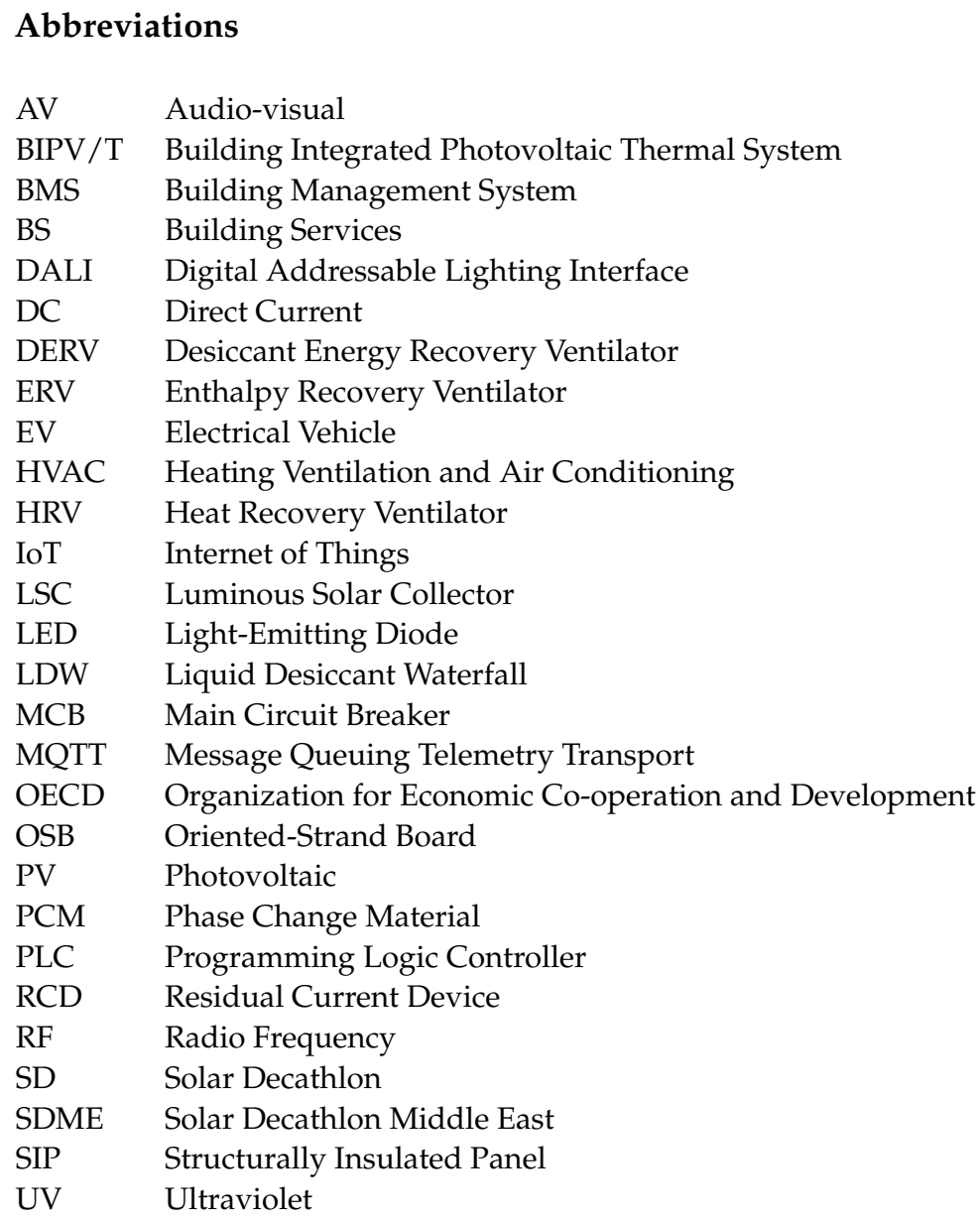

\section{References}

1. Pullen, S.; Chiveralls, K.; Zillante, G.; Palmer, J.S. Minimising the impact of resource consumption in the design and construction of buildings. In Proceedings of the ASA2012: 46th Annual Conference of the Architectural Science Association (Formerly ANZAScA)-Building on Knowledge: Theory and Practice, Griffith University, Brisbane, Australia, 14-16 November 2012; pp. 1-8.

2. Drucker, P. The essential Drucker: The Best of Sixty Years of Peter Drucker's Essential Writings on Management; Harper Collins: New York, NY, USA, 2001.

3. Porter, M. Competitive advantage of nations. Compet. Intell. Rev. 1990, 1, 14.

4. Banbury, C.; Mitchell, W. The effect of introducing important incremental innovations on market share and business survival. Strateg. Manag. J. 1995, 16, 161-182. [CrossRef]

5. Organizations for Economic Co-Operation and Development Statistical Office of the European Communities. Oslo Manual Guidelines for Collecting and Interpreting Innovation. Available online: https://ec.europa.eu/eurostat/documents/3859598/58 89925/OSLO-EN.PDF.pdf/60a5a2f5-577a-4091-9e09-9fa9e741dcf1?t=1414781154000 (accessed on 15 April 2021).

6. Solar Decathlon. Solar Decathlon: About Solar Decathlon. Available online: https://www.solardecathlon.gov/about.html (accessed on 20 October 2020).

7. Rules and Building Code-Solar Decathlon Middle East 2018. Available online: https://www.solardecathlonme.com/image/ catalog/documents/sdme-rules.pdf (accessed on 20 October 2020).

8. Eastment, M.; Hayter, S.; Nahan, R.; Stafford, B.; Warner, C.; Hancock, E.; Howard, R. Solar Decathlon 2002: The Event in Review. Available online: https://www.nrel.gov/docs/fy04osti/33151.pdf (accessed on 20 October 2020).

9. Moon, S.; Nahan, R.; Warner, C.; Wassmer, M. Solar Decathlon 2005: Event in Review 7-16 October 2005. Available online: https:/ / www.nrel.gov/docs/fy04osti/38264.pdf (accessed on 20 October 2020).

10. Sánchez, S.V.; Murcutt, G.; Ernst, W.; Mumovic, D.; Pich, F.; Baurier, A.; Koleeny, J.; García, P.J.; Wheeler, J.; Dunay, R.; et al. Solar Decathlon Europe 2010 Towards Energy Efficient Building. Available online: https:/ /download.hrz.tu-darmstadt.de/media/FB1 5/FGee/SOLAR-DECATHLON-EUROPE-2010.pdf (accessed on 23 October 2020).

11. Sánchez, S.V.; Torre, S.; Kolleeny, J.; Todorovic, M.; Urculo, R.; Pilkington, H.; Twill, J.; Unimas, E.R.; Rollet, P.; Bonnevie, J.; et al. Solar Decathlon Europe 2012_Improving Energy Efficient Buildings; Imprenta Kadmos: Salamanca, Spain, 2013. 
12. Warner, C.; Farrar-Nagy, S.; Wassmer, M.; Stafford, B.; King, R.; Sánchez, S.V.; Ubiñas, E.R.; Cronemberger, J.; María-Tomé, J.S. The 2009 Department of Energy Solar Decathlon and the 2010 European Solar Decathlon-Expanding the global reach of zero energy homes through collegiate competitions. In Proceedings of the 34th IEEE Photovoltaic Specialists Conference (PVSC), Philadelphia, PA, USA, 7-12 June 2009; pp. 002121-002125.

13. Nundy, S.; Mesloub, A.; Alsolami, B.M.; Ghosh, A. Electrically actuated visible and near-infrared regulating switchable smart window for energy positive building: A Review. J. Clean. Prod. 2021, 126854. [CrossRef]

14. Ghosh, A. Potential of building integrated and attached/applied photovoltaic (BIPV/BAPV) for adaptive less energy-hungry building's skin: A comprehensive review. J. Clean. Prod. 2020, 276, 123343. [CrossRef]

15. Bowen, G. Document analysis as a qualitative research method. Qual. Res. J. 2009, 9, 27-40. [CrossRef]

16. O'Leary, Z. The Essential Guide to Doing Research; Vistaar Publications: New Delhi, India, 2005.

17. U.S. Department of Energy. 2005 Solar Decathlon Rules and Regulations. Available online: https:/ /www.solardecathlon.gov/ past/pdfs/05_rulesregs/sd05rr_all.pdf (accessed on 20 October 2020).

18. U.S. Department of Energy. 2007 Solar Decathlon Rules and Regulations. Available online: https://www.solardecathlon.gov / past/pdfs/07_techreport/07_rulesregs.pdf (accessed on 20 October 2020).

19. U.S. Department of Energy. 2009 Solar Decathlon Rules. Available online: https://www.solardecathlon.gov/past/pdfs/09 _techreport/09_rules.pdf (accessed on 20 October 2020).

20. U.S. Department of Energy. U.S. Department of Energy Solar Decathlon 2011 Rules. Available online: https://www. solardecathlon.gov/past/2011/pdfs/2011_rules.pdf (accessed on 20 October 2020).

21. U.S. Department of Energy. U.S. Department of Energy Solar Decathlon 2013 Rules. Available online: https://www. solardecathlon.gov/past/2013/pdfs/2013_rules.pdf (accessed on 20 October 2020).

22. U.S. Department of Energy. U.S. Department of Energy Solar Decathlon 2015 Rules. Available online: https://www. solardecathlon.gov/2015/assets/pdfs/2015_rules.pdf (accessed on 21 October 2020).

23. U.S. Department of Energy. U.S. Department of Energy Solar Decathlon 2017 Rules. Available online: https://www. solardecathlon.gov/2017/assets/pdfs/sd2017-rules_final.pdf (accessed on 21 October 2020).

24. Organizing Committee of Solar Decathlon China. Solar Decathlon China Rules. Available online: https://www.scribd.com/ document/394982436/SDC2018-Rules-V2-2-pdf (accessed on 21 October 2020).

25. McCarthy, T.J.; Banfield, B.; Baghi, Y.; Faidutti, L.; McDowell, C. Advocating for Net-Zero Energy Sustainable Houses through the International Solar Decathlon Competition. In Proceedings of the 3rd World Congress on Civil, Structural, and Environmental Engineering (CSEE'18), Budapest, Hungary, 8-10 April 2018.

26. Cheng, C.; Rongwen, D.; Hao, Z. The analysis of passive design in Zero-energy buildings: A case study of solar Decathlon. Adv. Mater. Res. 2013, 689, 119-124. [CrossRef]

27. Team UOW. Desert Rose Project Manual. Available online: https://www.solardecathlonme.com/2018/teams/team-uow (accessed on 21 October 2020).

28. Cornell University. Comprehensive Assessment of Thermal Comfort Report. Available online: https://www.solardecathlon.gov/ past/pdfs/05_techreport/cornell_thermal_comfort_report.pdf (accessed on 21 October 2020).

29. National Renewable Energy Laboratory for the U.S. Department of Energy. Solar Decathlon 2009 Highlights of Team Innovations and Cutting-Edge Building Technologies. Available online: https://www.solardecathlon.gov/past/pdfs/09_techreport/ innovations.pdf (accessed on 21 October 2020).

30. Team Maryland. As-Built Project Manual. Available online: https://www.solardecathlon.gov/past/2011/pdfs/umd_manual.pdf (accessed on 21 October 2020).

31. Team Purdue. Project Manual As-built Documentation. Available online: https://www.solardecathlon.gov/past/2011/pdfs/ pur_manual.pdf (accessed on 22 October 2020).

32. Victoria University of Wellington First Light. Project Manual. Available online: https://www.solardecathlon.gov/past/2011 /pdfs/nz_manual.pdf (accessed on 21 October 2020).

33. Team Middlebury. Design Development Project Manual. Available online: https://www.solardecathlon.gov/past/2011/pdfs/ midd_manual.pdf (accessed on 22 October 2020).

34. The Ohio State University. Project Manual. 2011. Available online: https://www.solardecathlon.gov/past/2011/pdfs/osu_ manual.pdf (accessed on 22 October 2020).

35. Team Med in Italy. Project Manual. 2012. Available online: http://www.sdeurope.org/wp-content/pdf/ROME_PM_7.pdf (accessed on 29 August 2017).

36. Counter Entropy Team. Jury Report. 2012. Available online: https://building-competition.org/file/5909f1952dd2ae34bd8096fe/ 9f396cf030463e3a45dcfe513be687484635e1ee1c9be17dfeee11109bcca38c (accessed on 23 October 2020).

37. Team Austria. Project Manual. 2011. Available online: https://www.solardecathlon.gov/past/2013/pdfs/vut_manual.pdf (accessed on 21 October 2020).

38. Team Las Vegas. As-Built Phase Project Manual. 2013. Available online: https://www.solardecathlon.gov/past/2013/pdfs/ unlv_manual.pdf (accessed on 23 October 2020).

39. Team Czech Republic. Project Manual As-Built Documentation. 2013. Available online: https://www.solardecathlon.gov/past/ 2013/pdfs/ctu_manual.pdf (accessed on 22 October 2020). 
40. Stanford University. As-Built Construction Documentation Project Manual. 2013. Available online: https://www.solardecathlon. gov/past/2013/pdfs/su_manual.pdf (accessed on 21 October 2020).

41. Team Lucerne. Project Manual. 2014. Available online: https://building-competition.org/file/5909f18f2dd2ae33eb8d15cd/6823 f6eaf05d9f23c394adf8ba2b0750cb28a7833c92defc1f777049cad289b7 (accessed on 21 October 2020).

42. Stevens Institute of Technology. Jury Narratives. 2015. Available online: https://www.solardecathlon.gov/2015/assets/pdfs/ sd2015_narrative_sit.pdf (accessed on 21 October 2020).

43. University at Buffalo the State University of New York. Jury Narratives. 2015. Available online: https: / / www.solardecathlon. gov/2015/assets/pdfs/sd2015_narrative_nybuff.pdf (accessed on 21 October 2020).

44. Missouri University of Science and Technology. Jury Narratives. 2015. Available online: https://www.solardecathlon.gov/2015 /assets/pdfs/sd2015_narrative_mst.pdf (accessed on 2 October 2020).

45. California Polytechnic State University. Jury Narratives. 2015. Available online: https://www.solardecathlon.gov/2015/assets/ pdfs/sd2015_narrative_calpoly.pdf (accessed on 21 October 2020).

46. University of Maryland. Engineering Narrative. 2017. Available online: https://www.solardecathlon.gov/2017/assets/pdfs/sd2 017_maryland_narrative_engineering.pdf (accessed on 22 October 2020).

47. Team Virginia Tech. FutureHAUS Project Manual. 2018. Available online: https://www.solardecathlonme.com/2018/teams/ team-virginia-tech (accessed on 22 October 2020).

48. Team EFden. EFdeN Signature Project Manual \#6. 2018. Available online: https://www.solardecathlonme.com/2018/teams/ team-efden (accessed on 22 October 2020).

49. Team Baitykool. Baitykool Project Manual \#6. 2018. Available online: https://www.solardecathlonme.com/2018/teams/teambaitykool (accessed on 22 October 2020).

50. Team Ikaros Bavaria. Solar System and Hot Water Brief Report. Available online: https://building-competition.org/file/5909f1 892dd2ae330fc57a0a/43a4003f48051a948123db74f7453cd28f8348c8ab37d94e8c7ad6ab0238abb5 (accessed on 23 October 2020).

51. Team HFT Stuttgart. Project Manual. Available online: https://building-competition.org/file/5909f18b2dd2ae334bec6098/a506 4c88063f4883ce707dd6a00970cd259ccae3f09c22f4b4e47b64a7fc8459 (accessed on 23 October 2020).

52. Ecolar Team. Project Manual. 2012. Available online: http://www.sdeurope.org/wp-content/pdf/HTWG_PM_7.pdf (accessed on 29 August 2017).

53. Universita Degli Studi di Roma TRE. Project Manual. 2014. Available online: http://www.solardecathlon2014.fr/ftp/docs/ ROME_PM7.pdf (accessed on 21 October 2020).

54. Cornell University. Comprehensive Assessment of Hot Water System Report. Available online: https://www.solardecathlon. gov/past/pdfs/05_techreport/cornell_hot_water_report.pdf (accessed on 21 October 2020).

55. Universidad Politécnica de Madrid. Casa Solar Construction Specifications. Available online: https://www.solardecathlon.gov/ past/download/07_techreport/madrid_tech_specs.zip (accessed on 15 April 2021).

56. Team Ontario/BC. Project Manual. Available online: http://www.solardecathlon.gov/past/download/09_construction_docs/ manual_ontario_bc.zip (accessed on 15 April 2021).

57. National Renewable Energy Laboratory for the U.S. Department of Energy. Solar Decathlon 2007 Highlights of Team Innovations and Cutting-Edge Building Technologies. Available online: https://www.solardecathlon.gov/past/pdfs/07_techreport/07 _innovations.pdf (accessed on 21 October 2020).

58. University of Minessota. Project Manual. Available online: http://www.solardecathlon.gov/past/download/09_construction_ docs/manual_minnesota.zip (accessed on 15 April 2021).

59. Team Alabama. Innovation Narrative. 2017. Available online: https://www.solardecathlon.gov/2017/assets/pdfs/sd2017_ alabama_narrative_innovation.pdf (accessed on 22 October 2020).

60. Technische Universität Darmstadt. TU Darmstadt Solar Decathlon 07 Specification. Available online: https://www. solardecathlon.gov/past/download/07_techreport/darmstadt_specs.zip (accessed on 15 April 2021).

61. Universidad Politécnica de Madrid. Casa Solar Madrid As-Built Drawings. Available online: https://www.solardecathlon.gov / past/download/07_techreport/madrid_as_built_drawings.zip (accessed on 15 April 2021).

62. Team Luuku House. Engineering and Construction Brief Report. Available online: https://building-competition.org/file/5909f1 8c2dd2ae3369033ffb /908ceb0c3152caf5d1a835b57aa274aeddff257558505b14b9d5c02050409060 (accessed on 23 October 2020).

63. Ecolar Team. Jury Report. 2012. Available online: https://building-competition.org/file/5909f1972dd2ae35031cf8b4/7cea0bf887 1b48e22dc30bb9142f00fa428987dfd0c678d57edd1e61dfc3dfc3 (accessed on 23 October 2020).

64. Stevens Institute Team. As-Built Project Manual. 2013. Available online: https://building-competition.org/file/5992e867ecb8f5 5195527287/edab3e409227d4ef928c4e9ba2e465b1bdb00b14519ad9f0df130684cebc69a7 (accessed on 21 October 2020).

65. Team Prê-à-Loger. Project Drawing. 2014. Available online: https://building-competition.org/file/5909f1902dd2ae33ffb78cf8/3 68028d6872eff3b6016b8ea8eb70a67c350bb86a2a61b9cd2cc6fc16e0206b8 (accessed on 21 October 2020).

66. Team Rooftop. Engineering and Construction Report. 2014. Available online: https://building-competition.org/file/5909f190 2dd2ae3409b62ab6/2bc69144e79424b8bf312cb196dbe1fe61820d1dba0f3eae756e0d534d54ed27 (accessed on 21 October 2020).

67. Rodríguez-Ubiñas, E.; Ruíz-Valero, L.; Sánchez, S.V.; González, F.J.N. Latent heat thermal energy storage systems in lightweight construction: Review of PCM applications in Solar Decathlon Houses. WIT Trans. Ecol. Environ. 2011, 150, $935-946$.

68. Powered by the Sun 2007 Solar Decathlon. Available online: https://www.nrel.gov/docs/fy07osti/41540.pdf (accessed on 21 October 2020). 
69. Andalucia Team. Project Manual. 2012. Available online: http://www.sdeurope.org/wp-content/pdf/AND_PM_7.pdf (accessed on 29 August 2017).

70. Sapienza Universita Di Roma. Project Manual. 2018. Available online: https://www.solardecathlonme.com/2018/teams/teamsapienza (accessed on 22 October 2020).

71. Wendt, A. German Team Wins Solar Decathlon. Building Green. Available online: https://www.buildinggreen.com/newsbrief/ german-team-wins-solar-decathlon (accessed on 21 October 2020).

72. Virginia Tech Team. As-Built Project Manual. Available online: https://building-competition.org/file/5909f18a2dd2ae3337cac5 e5/113ecf2a21b69dfb172fffe4d1643612e83becbeecf5b0f721cb86ced3f1f980 (accessed on 23 October 2020).

73. Team Canopea. Jury Brief. Available online: https://building-competition.org/file/5909f1972dd2ae35177746d4/b380e38a75995 62e60e25c341583f6ff210aa41056b3729a2a754c8d760f094e (accessed on 22 October 2020).

74. Team Med in Italy. Jury Report. 2012. Available online: https://building-competition.org/file/5909f1962dd2ae34efb63b4c/cd015 4492119813b7886d3551290b555f4186e1ff2ae88bd7cac1bc5f1bd9c40 (accessed on 23 October 2020).

75. Visitors Guide Solar Decathlon 2013. 2013. Available online: https://www.solardecathlon.gov/past/2013/pdfs/2013_visitors_ guide.pdf (accessed on 21 October 2020).

76. Universita Degli Studi di Roma TRE. Project Drawing. 2014. Available online: http://www.solardecathlon2014.fr/ftp/docs/ ROME_PD7.pdf (accessed on 21 October 2020).

77. Atlantic Challenge Team. Project Manual. 2014. Available online: http:/ / www.solardecathlon2014.fr/ftp/docs/ATC_PM7.pdf (accessed on 21 October 2017).

78. Team Prê-à-Loger. Project Manual \#7. 2014. Available online: https:// building-competition.org/file/5909f1902dd2ae33ffb78cf8 /2f8c45fd02e7616363ff63e9ac1e1da8c77e1aeaee785074178a1f9e04ca6872 (accessed on 3 November 2014).

79. Team Rooftop. Project Manual. 2014. Available online: https://building-competition.org/file/5909f1902dd2ae3409b62ab6/80c8 5a0fa31c10da582349c89f2d673b717ac77211c61278450d72419a385fdc (accessed on 21 October 2020).

80. University of Texas at Austin; Technische Universitaet Muenchen. Jury Narratives. 2015. Available online: https://www. solardecathlon.gov/2015/assets/pdfs/sd2015_narrative_tex.pdf (accessed on 22 October 2020).

81. Swiss Living Challenge Team. Innovation. 2017. Available online: https://www.solardecathlon.gov/2017/assets/pdfs/sd2017_ swissteam_narrative_innovation.pdf (accessed on 21 October 2020).

82. Missouri University of Science and Technology. Innovation Narrative. 2017. Available online: https://www.solardecathlon.gov/ 2017/assets/pdfs/sd2017_missouri_narrative_innovation.pdf (accessed on 21 October 2020).

83. Fonts, A. Santa Clara University Specifications. Available online: https://www.solardecathlon.gov/past/download/07 _techreport/santa_clara_specs.zip (accessed on 15 April 2021).

84. University of Maryland. Construction Drawings. 2017. Available online: https://www.solardecathlon.gov/2017/assets/pdfs / maryland-drawings.pdf (accessed on 22 October 2020).

85. UC Berkley; University of Denver. Innovation Narrative Submission. 2017. Available online: https://www.solardecathlon.gov/ 2017/assets/pdfs/sd2017_berkeleydenver_narrative_innovation.pdf (accessed on 21 October 2020).

86. Team Ikaros Bavaria. Sustainability Brief Report. Available online: https://building-competition.org/file/5909f1892dd2ae330fc5 7a0a/35d40a6429c44cb414ff2832be2e143ba62f2b4bfe309cf7b7502c80cba9dbe5 (accessed on 23 October 2020).

87. Swiss Living Challenge. Construction Specifications. 2017. Available online: https:/ /www.solardecathlon.gov/2017/assets / pdfs / swiss-specs.pdf (accessed on 24 October 2020).

88. Frascarolo, M.; Martorelli, S.; Vitale, V. An innovative lighting system for residential application that optimizes visual comfort and conserves energy for different user needs. Energy Build. 2014, 83, 217-224. [CrossRef]

89. Cornell University. Electric Lighting Quality. Available online: https://www.solardecathlon.gov/past/pdfs/05_techreport/ cornell_electric_lighting_report.pdf (accessed on 21 October 2020).

90. Virginia Polytechnic Institute; State University. Lighting. Available online: https://www.solardecathlon.gov/past/pdfs/05 _techreport/va_tech_electric_lighting_report.pdf (accessed on 21 October 2020).

91. University of Maryland. Innovation Narrative. 2017. Available online: https://www.solardecathlon.gov/2017/assets/pdfs/sd2 017_maryland_narrative_innovation.pdf (accessed on 21 October 2020).

92. New York Institute of Technology. NYIT Brief Contest Report: Dwelling. Available online: https://www.solardecathlon.gov/ past/pdfs/05_techreport/nyit_dwelling_report.pdf (accessed on 11 April 2021).

93. Andalucia Team. Jury Report. 2012. Available online: http://www.sdeurope.org/wp-content/pdf/AND_JuryBriefReports.pdf (accessed on 29 August 2017).

94. Liedl, P.; Pyrek, A.; Garrison, M.; Upshaw, C.; Lang, W. The Nexushaus: Get connected in central Austin. J. Green Build. 2015, 10, 44-54. [CrossRef]

95. Weber, E. Creating the UNLV Solar Decathlon House: Processes and lessons. Int. J. Architecton. Spat. Environ. Des. 2014, 8, 17-31. [CrossRef]

96. Yang, X.Q.; Yang, W.; Gao, H. The life cycle oriented concepts of zero energy solar house: A review of SDE2010 projects. Appl. Mech. Mater. 2013, 361, 281-285. [CrossRef]

97. Stieldorf, K. Building physics, design, and the collaborative build: Sustainability and resilience in architectural education. Archit. Des. 2018, 88, 102-109. [CrossRef] 
98. DOE Solar Decathlon. New Zealand Virtual Tour-Solar Decathlon 2011. Available online: https://www.youtube.com/watch?v= OJnoextCURc (accessed on 23 October 2020).

99. Team Armadillo Box. Project Manual. Available online: https://building-competition.org/file/5909f18d2dd2ae33a54b21c4/2 5fc54de48b49f43e1206677a250fac5e38f1b16c0f7407bd3ff1aa217393df7 (accessed on 23 October 2020).

100. Team Prê-à-Loger. Engineering \& Construction. 2014. Available online: https://building-competition.org/file/5909f1902dd2ae3 3ffb78cf8/0d430d1c783ac7d6525499caf0e4e236eda60409fd491095660703ac86690aa8 (accessed on 21 October 2020).

101. Casini, M. A positive energy building for the Middle East climate: ReStart4Smart solar house at solar decathlon Middle East 2018. Renew. Energy 2020, 159, 1269-1296. [CrossRef]

102. Solar Calpoly Team. Thermal Comfort Comprehensive Assessment Report. Available online: https://www.solardecathlon.gov/ past/pdfs/05_techreport/calpoly_thermal_comfort_report.pdf (accessed on 21 October 2020).

103. Team California. Project Manual. 2009. Available online: http://www.solardecathlon.gov/past/download/09_construction_ docs/manual_california.zip (accessed on 15 April 2021).

104. Ma, Z.; Ren, H.; Lin, W. A review of heating, ventilation and air conditioning technologies and innovations used in solar-powered net zero energy Solar Decathlon houses. J. Clean. Prod. 2019, 240, 118158. [CrossRef]

105. Solar Decathlon 2009. 2009. Available online: https://www.nrel.gov/docs/fy09osti/45753.pdf (accessed on 21 October 2020).

106. New York Institute of Technology. NYIT Brief Contest Report: Architecture. 2005. Available online: https://www.solardecathlon. gov/past/pdfs/05_techreport/nyit_architecture_report.pdf (accessed on 21 October 2020).

107. Team Ikaros Bavaria. Architectural Brief Report. 2010. Available online: https://building-competition.org/file/5909f1892dd2ae3 30fc57a0a/753604629be4cbcdfd70029998ecdb2becafeee923bbc4d6dfc210cc0fd6352f (accessed on 23 October 2020).

108. Snell, C. Practical resilience: Low-tech plug-and-play innovation in the SU + RE house. Archit. Des. 2018, 88, 56-63. [CrossRef]

109. Battista, G.; Carnielo, E.; Evangelisti, L.; Frascarolo, M.; Vollaro, R. Energy performance and thermal comfort of a high efficiency house: RhOME for denCity, winner of solar decathlon Europe 2014. Sustainability 2015, 7, 9681-9695. [CrossRef]

110. Garrison, M. The 2005 Solar D house. WIT Trans. Built Environ. 2006, 86, 155-162.

111. Technische Universität Darmstadt. Project Manual. 2009. Available online: http://www.solardecathlon.gov/past/download/09 construction_docs/manual_germany.zip (accessed on 15 April 2021).

112. Team HFT Stuttgart. Architectural Brief Report. 2010. Available online: https://building-competition.org/file/5909f18b2dd2ae3 34bec6098/e0ece1f33ea9ca9d641bac99d3d9a33c06b16c7e63c276f6062d5b2848e51980 (accessed on 23 October 2020).

113. Pujadas-Gispert, E.; Alsailani, M.; van Dijk, K.C.A.; Rozema, A.D.K.; ten Hoope, J.P.; Korevaar, C.C.; Moonen, S.P.G. Design, construction, and thermal performance evaluation of an innovative bio-based ventilated façade. Front. Archit. Res. 2020, 9, 681-696. [CrossRef]

114. Liu, H.; Gao, H.; Wan, D. Research on building construction system of SDE2010. Adv. Mater. Res. 2011, 368, 3638-3642. [CrossRef]

115. University of Illinois at Urbana-Champaign. Construction Drawing. 2009. Available online: http://www.solardecathlon.gov/ past/download/09_construction_docs/cd_illinois.zip (accessed on 15 April 2021).

116. Team Solar CalPoly. Architecture Report. 2005. Available online: https://www.solardecathlon.gov/past/pdfs/05_techreport/ calpoly_architecture_report.pdf (accessed on 21 October 2020).

117. Luna-Tintos, J.; Cobreros, C.; López-Escamilla, Á.; Herrera-Limones, R.; Torres-García, M. Methodology to Evaluate the Embodied Primary Energy and $\mathrm{CO}_{2}$ Production at Each Stage of the Life Cycle of Prefabricated Structural Systems: The Case of the Solar Decathlon Competition. Energies 2020, 13, 4311. [CrossRef]

118. Virginia Polytechnic Institute; State University. Dwelling. 2005. Available online: https://www.solardecathlon.gov/past/pdfs/ 05_techreport/va_tech_dwelling_report.pdf (accessed on 21 October 2020).

119. Cronemberger, J.; Corpas, M.; Cerón, I.; Caamaño-Martín, E.; Sánchez, S. BIPV technology application: Highlighting advances, tendencies and solutions through solar decathlon Europe houses. Energy Build. 2014, 83, 44-56. [CrossRef]

120. Zanelli, A.; Spinelli, L.; Monticelli, C.; Pedrali, P. Lightweight Landscape; Springer International Publishing: Cham, Switzerland, 2016.

121. DOE Solar Decathlon. Maryland's Solar Decathlon 2011 Architecture Audio-Visual Presentation. 2011. Available online: https: / / www.youtube.com/watch?v=IAzO-wdKUxg (accessed on 23 October 2020).

122. Team Maryland. Construction Drawing. 2011. Available online: https://www.solardecathlon.gov/past/2011/pdfs/umd_cd.pdf (accessed on 21 October 2020).

123. University of Nevada Las Vegas. Construction Drawing. 2013. Available online: https://www.solardecathlon.gov/past/2013 /pdfs/unlv_cd.pdf (accessed on 21 October 2020).

124. Firstlight, N.Z. First Light NZ—Solar Decathlon—Walkthrough. 2011. Available online: https:/ /www.youtube.com/watch?v=J5 5Ad-95rCA (accessed on 23 October 2020).

125. DOE Solar Decathlon. Middlebury College's Solar Decathlon 2011 Video Walkthrough. 2011. Available online: https:/ www youtube.com / watch?v=YxrXCbgCsoY (accessed on 23 October 2020).

126. Samuel, A.K.; Mohanan, V.; Sempey, A.; Garcia, Y.F.; Lagiere, P.; Bruneau, D.; Mahanta, N. Sustainable approach for a climate responsive house in United Arab Emirates: Case study of SDME 2018 BAITYKOOL project. In Proceedings of the 2019 International Conference on Computational Intelligence and Knowledge Economy (ICCIKE), Dubai, United Arab Emirates, 11-12 December 2019. 
127. SolarHaus TU Darmstadt. Solar Decathlon 2007. 2020. Available online: http://eud.leneurbanity.com/6-most-sustainable-andenergy-efficient-designs-for-the-future-of-urban-housing/peh_bmvbs_2/ (accessed on 21 October 2020).

128. SolarHaus TU Darmstadt. Solar Decathlon 2007. 2020. Available online: http:/ / eud.leneurbanity.com/6-most-sustainable-andenergy-efficient-designs-for-the-future-of-urban-housing/peh_bmvbs_1/ (accessed on 21 October 2020).

129. University of Colorado. Dwelling in the cu "BIO-S ${ }^{(\mathrm{H})} \mathrm{IP}^{\prime}$. 2005. Available online: https://www.solardecathlon.gov/past/pdfs / 05_techreport/co_dwelling_report.pdf (accessed on 21 October 2020).

130. Zhang, S.; Liu, H.; Wang, Y. New trends of green building's skin material: Take the solar decathlon Europe 2010 for example. Adv. Mater. Res. 2013, 671, 1905-1908. [CrossRef]

131. Enware. Enware and UOW Create Dementia-Friendly House of the Future. 2020. Available online: https://www.enware.com. $\mathrm{au} /$ news/enware-and-uow-create-dementia-friendly-house-of-the-future (accessed on 22 October 2020).

132. Ghosh, A. Possibilities and challenges for the inclusion of the electric vehicle (EV) to reduce the carbon footprint in the transport sector: A review. Energies 2020, 13, 2602. [CrossRef] 